Portland State University

PDXScholar

Fall 12-8-2016

\title{
The Effectiveness of Participation in a Project-based Learning Project on At-risk Student Self-Efficacy
}

Benjamin Aaron Weber

Portland State University

Follow this and additional works at: https://pdxscholar.library.pdx.edu/open_access_etds

Part of the Science and Mathematics Education Commons Let us know how access to this document benefits you.

Recommended Citation

Weber, Benjamin Aaron, "The Effectiveness of Participation in a Project-based Learning Project on At-risk Student Self-Efficacy" (2016). Dissertations and Theses. Paper 3363.

https://doi.org/10.15760/etd.5254

This Thesis is brought to you for free and open access. It has been accepted for inclusion in Dissertations and Theses by an authorized administrator of PDXScholar. Please contact us if we can make this document more accessible: pdxscholar@pdx.edu. 
The Effectiveness of Participation in a Project-based Learning Project on At-risk

Student Self-Efficacy

by

Benjamin Aaron Weber

A thesis submitted in partial fulfillment of the requirements for the degree of

Master of Science in Teaching

in

General Science

Thesis Committee:

William Becker, Chair

Susan Duncan

Michael Ellison

Stephanie Wagner

Portland State University

2016 


\begin{abstract}
Project-based learning is a multifaceted approach to teaching in which students explore real-world problems and challenges while working in small collaborative groups. Project-based learning is active and engaging and drives students to obtain a deeper knowledge of the subjects they're studying, and students develop confidence and selfdirection as they move through both team-based and independent work. This project endeavored to assess the effect of participation in a project-based learning (PBL) activity of the Wind and Oar Boat School's curriculum on the self-efficacy of at-risk high school students. Twenty students participated in the program for both math and applied arts credits needed to complete their high school graduation requirements. Data were collected using a retrospective pre-then-post survey, participant observations, and semistructured interviews. To assess student Self-efficacy, the researcher observed six constructs of self-efficacy, those being motivation, problem- solving, resilience, teamwork, confidence, and course skills. The findings were utilized to create student narratives that documented the experiences of the students in the program and provide the student side of the program and the changes that happened because of their participation in the program. Analysis of the retrospective survey confirmed that the students had statistically significant increases in all the constructs of self-efficacy, which was congruent with literature citations, researcher observations, and student interviews.
\end{abstract}

Keywords: Self-efficacy, Project-Based Learning, Motivation, Resilience, Teamwork, Communication, Problem Solving, At-risk Students 


\section{Dedication}

To my wife, Pamela,

Without your understanding and patience of my late-night study sessions, I know that I would not be here today. Thank you, my love, for everything you did for me over the past two years. 


\section{Acknowledgements}

Special thanks to the faculty of the Center for Science Education at Portland State University. William Becker, you were a great mentor who guided me throughout this long process. Your suggestions and ideas were greatly appreciated. Stephanie Wagner, like so many have said before me, you are the greatest recruiter and grabbed me at the door and never let me think of leaving this great program. Michael Ellison, your knowledge, and analysis were instrumental in my finally understanding what data I had collected and your directions on how to look at it made this whole project come together. Susan Duncan, your day to day positivity and encouraging nature gave me the boost of energy to keep going. Finally, to Peter Crim and Jann Lane and the incredible instructors at the Wind \& Oar Boat School that made it look so easy. 
Table of Contents

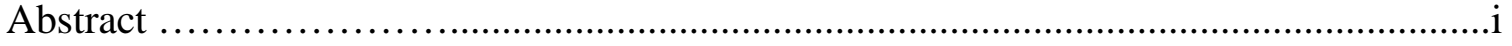

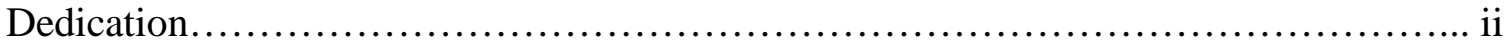

Acknowledgements........................................................ii

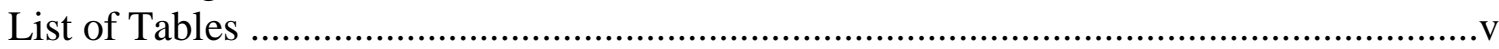

Chapter 1

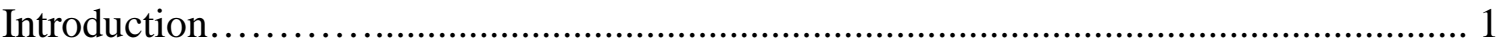

Chapter 2

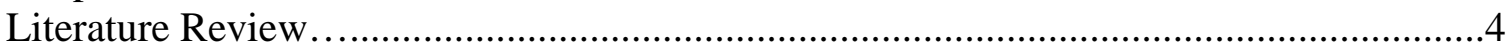

Chapter 3

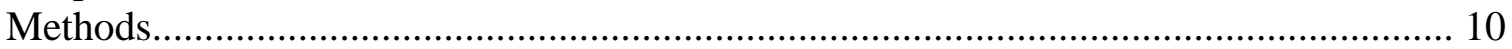

Chapter 4

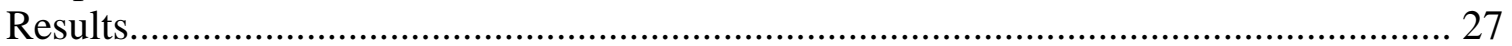

Chapter 5

Exemplar of the Program.......................................................63

Chapter 6

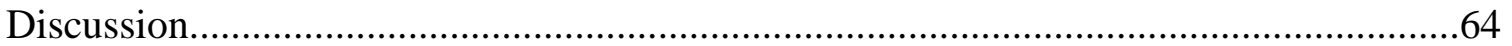

Chapter 7

Limitations.................................................................. 71

Chapter 8

Recommendations.............................................................. 74

Chapter 9

Conclusion..............................................................76

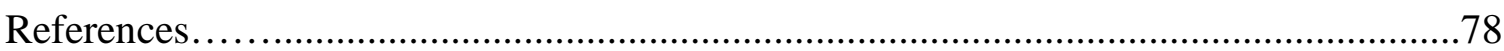

Appendix

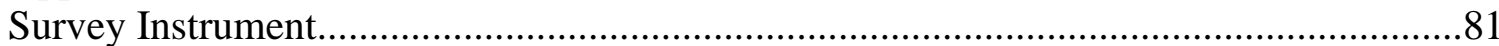


List of Tables

Table 1. Student Demographics ..............................................11

Table 2. Observations..................................................... 19

Table 3. The Wind and Oar Boat course outline.............................27

Table 4. Test Statistics A................................................31

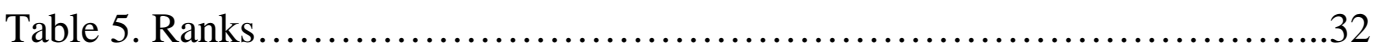

Table 6. Test Statistics B.................................................33

Table 7. Motivation...................................................... 34

Table 8. Student attendance.............................................. 37

Table 9. Course Skills.................................................39

Table 10. Resilience......................................................41

Table 11. Teamwork..................................................44

Table 12. Confidence................................................46

Table 13. Problem Solving...........................................49

Table 14. Constructs of Self-Efficacy...................................65 


\section{Chapter 1: Introduction}

EDFacts (2015) reports that while the U.S. is graduating more high school students than ever, one in five students still fail to earn a high school diploma. Washington D.C., Oregon, and New Mexico posted the worst graduation rates in the country. The overall graduation rates for the United States, Oregon is second to the bottom. Taking this into account educators and administrators want to know how they can nurture student self-efficacy which correlates to higher student engagement and increased graduation rates (Hammond, 2014). Some schools have done this by looking at non-traditional instructional environments like the Wind and Oar boat building course.

The Wind and Oar Boat course have students building a full-sized seaworthy vessel from drawings utilizing an innovative and unique platform. The class works as a boat building team at the school site participating in a curriculum that is designed to foster student self-efficacy and motivational resilience. Larson (2000) proposes that the contexts well suited to promote engagement are activities that are by their nature structured around group participation. Each step in building a boat, from concept design, reviewing plans, reading plans, scaling up materials, fitting and shaping parts, mastering tools, is an opportunity to teach and reinforce student self-efficacy and motivational resilience, as well as the Science, Technology, Engineering, Math (STEM) skills and artistic skills used in the boat building process.

This study sought to measure how the participation in a project-based learning (PBL) activity of building a boat affected academic identity and motivational resilience i.e. self-efficacy of high school students. This research took place at a small, nontraditional community high school located in the suburbs of a metropolitan city in the 
Pacific Northwest. The program is designed for students who want the support of a small community of teachers and students. Many of the students who attend the "Community High School do not feel like they "fit in" at a mainstream high school. They want to do well in school, but need support in building academic skills and habits, and dealing with issues that distract them from learning. Community High School is designed to help students take responsibility for their learning and their lives (https://www.beaverton.k12.or.us/schools/merlo-station-chs/, 2016)."

This study included 20 at-risk students. As defined by San Martin and Calabrese (2011) an "at-risk" student is usually described as a student who is likely to fail at school or drop out of school before high school graduation. Thus, the characteristics of at-risk students have traditionally been identified through retrospective examinations of high school dropouts' family and school histories. These features associated with dropping out of school then become the defining characteristics of at-risk students. Many of the youth in this program come from communities with low socioeconomic status (SES) or from public housing neighborhoods.

My role was a participant observer, recording how the students interact with the instructors and each other. The students were administered a retrospective pre- then postdesign academic self-efficacy assessment. Data was collected via researcher observations and post-course individual student interviews. The self-efficacy assessment survey consisted of 29 questions that sought to determine the student's perceived level of selfefficacy after their participation the in the PBL activity of building a boat while attending the Wind and Oar Boat School course offered at their high school. 
Through the analysis of the self-efficacy surveys, student interviews and researcher observations, the researcher formulated knowledge claims that addressed the research question of how the participation in a project-based learning activity of building a boat impacts student self-efficacy. 


\section{Chapter 2: Literature Review}

\section{Self-efficacy}

A primary source of human motivation is rooted in cognitive activity. In cognitively generated motivation, people motivate themselves and guide their actions through the exercise of forethought. They anticipate likely outcomes of proposed actions, set goals for themselves, and plan courses of action designed to realize valued futures “delayed gratification.” Events that have not occurred are not reasons for motivation in the present. People are motivated to achieve future events by accomplishing immediate goals and translating the current success into future goals and attitudes. Current motivation or present actions do not derive from a potentiality and visualization of a present event can be changed into motivators for a future outcome. Planning and putting into action goals can be turned into a motivation for action through the "self-regulatory mechanisms (Bandura, 1997). The establishment of targets impacts self-reflection and the perceived self-efficacy of the individual. The greater the perceived self-efficacy of a person the bigger the goals that person sets for themselves. (Locke, Frederick, Lee, \& Bobko, 1984, Ponton, Rhea, 2006). Goals and intrinsic values operate mainly through self-referent processes rather than regulate motivation and action directly. Goals motivate by enlisting self-evaluative connection in the activity. People seek self-satisfaction from fulfilling valued goals and are prompted to strengthen their efforts by displeasure with failure. A person's level of understanding of self-efficacy drives the degree of control a person has on their motivation. When choosing a challenge that a person wants to undertake, that person will base that their decision on their self-beliefs of efficacy, and how to continue when they encounter hardships (Bandura,1988). The stronger the 
confidence in their capabilities, the more persistent they will be in their efforts. When a person is unable to accomplish what, they set out to do, or they do not perform up to what they expect of themselves, uncertainty and doubt in their capabilities become diminished. Which in turn causes many to quit or put less effort into the task they are attempting to achieve. On the other hand, people that have high self-efficacy will endure setbacks and continue to perform at higher levels than those without that self-assurance. Steady perseverance pays off in performance accomplishments (Ponton, Rhea, 2006, Cervone \& Peake, 1986).

One aspect that affects the achievement of students in education is the selfefficacy perceptions toward the lessons. Bandura (1997) detailed self-efficacy as being defined as a set of beliefs or expectations a person has about their aptitude to achieve given tasks successfully. Studies have shown, that self-efficacy perception is an important determinant of students' achievement (Pajares and Miller, 1994). Pajares and Miller (1994) found that personal beliefs affect student achievement in both a positive and adverse manner.

Self-efficacy is an understanding of oneself grounded upon the processing of information. In this regard, self-reflection is the form of functioning that influences efficacy assessments. An individual will assess the effectiveness of a situation and the behavior of others and themselves based on their past experiences and their personal beliefs. Behavior and environment provide four sources of efficacy information: mastery experiences, physiological/emotive stimulations, shared experiences, and verbal persuasion (Bandura, 1997). The influence of these four sources on efficacy depends on upon the individual's interpretation of the information provided. For instance, past 
successes attributed to outside assistance rather than personal ability would not enhance self-efficacy (Bandura, 1997).

Project-Based Learning

Schools have sought reforms in various means. One initiative that shows promise comes under the umbrella of constructivist learning models. On strategy in this area is that of “project-based learning” or PBL. In project-based learning, learners work in groups to solve problems that are realistic, curriculum-based, and usually interdisciplinary in scope. Contrary to traditional lessons in PBL activities, the students decide how to approach a problem and what activities will be used to pursue the solution. Students are encouraged to gather information from a variety of sources and synthesize, analyze, and derive knowledge from it. Their learning is fundamentally valuable because it is connected to something tangible and involves skills utilized by adults outside of the classroom, such as collaboration and reflection. Finally, learners demonstrate their newly acquired knowledge and are critiqued by how much they have learned. As The teacher's role is to guide and advise, rather than to direct and manage, student work throughout this process (Solomon, 2003).

This model inspires students to use higher order thinking skills to solve real world problems that impact their lives not just inside the classroom but in their daily lives as well. In her article on the power of projects, Curtis (2002) looked at PBL in action and provided substantial instances of how students used it. In her research, for example, she found students who were designing a school for the year 2050, as well as students who were working on building a sidewalk to connect campus buildings. Thus, demonstrating, that project-based learning can range from the concrete to the very abstract. Curtis 
pointed out positive aspects of PBL. Those being: differentiated courses to meet the diverse needs of students, increased retention as students are applying what they learn to areas that interest them, an overall increase in attendance, and a noticeable decrease in behavior issues. Conversely, there are challenges with implementing project-based learning into a classroom. These include time management; difficulty in identifying realistic projects that meet curriculum requirements; increased workload in planning for the PBL lessons; and meeting the students' diverse needs as they explore projects from divergent perspectives.

Thomas (2000) looked at different aspects of project-based learning. He divided PBL into four categories, including summative and formative evaluations of PBL; a section on what student characteristics lead to success with problem-based learning models; and what can be done to implement PBL more efficiently. An additional portion of Thomas' research focuses on potential problems with implementation.

Thomas, like Curtis, found a myriad of factors that impact the implementation of PBL lessons. One of note is time; projects often take longer than anticipated. Additionally, there are other difficulties that teachers experience in incorporating ProjectBased Science activities into district guidelines are aggravated by the time necessary to implement in-depth approaches to PBL. Another factor that impacts the PBL implementation is classroom management. Some teachers have difficulty structuring students' activities, which can lead to giving them too much independence or too little modeling and feedback. Thomas (2000) concluded that PBL is popular among students and teachers, has the potential to increase learning engagement, and lends itself to deeper 
learning, higher level thinking and increased the ability to apply the knowledge gained. Disadvantages include difficulties in implementation.

In Katz \& Chard (1999) look at project-based learning in the primary grades, they aimed to define the nature of a project. Elements of the project approach described; distinctions between differing approaches and concrete examples being used. A problem is identified, and an investigation starts. This method depends on students taking an active role in their learning. Their study focuses on young learners, so advice is given to help make this approach meaningful to them. The researchers relay the importance of choosing topics young students can relate. They referred to this learning as having vertical or horizontal relevance. These terms are defined as follows. "Vertical connection relates to the knowledge that is intended to prepare children for the next class or the next school; horizontal relevance relates to learning experiences that are meaningful at the time they are experienced” (Katz \& Chard 1999, p.9). They point out that as students grow and become increasingly confident, more abstract, vertical type learning experiences will be made more successful. They also stated that many schools focus on a more traditional approach. As noted by the researchers, "The content of these exercises is often unrelated to the world in which they live and learn” (Katz \& Chard 1999, p.12). On the other hand, they define the traditional nursery or kindergarten approach, being one that focuses on the arts and spontaneous play. These researchers suggested that neither approach is perfect, but a more balanced approach is essential. They advocated for an approach that places more value on intellectual goals. Per Katz \& Chard (1999), this would be an approach where "Children's minds are engaged in ways that deepen their understanding of their experiences and environment and thereby strengthen their 
confidence in their intellectual powers...dispositions to observe and investigate, for example (p. 7)".

In Project-Based Learning, students need to apply what they learn academically in a real project. The project affords the students the opportunity to put their knowledge and acquired skills on a real task that is not like many other class projects that are only theoretical in nature. PBL activities are structured along an open-ended essential question that teachers use to connect the content to relevant issues to the students. Through this process, apply that knowledge to products they produce. Also, PBL by its nature creates more rigorous learning activity, where students are active participants in the activity which facilitates greater understanding of the concepts, and it enables them to develop useful skills, which foster higher self-efficacy. Since students can apply classroom content to realistic phenomena, PBL also assists career exploration, technology use, student engagement, community connections, and content relevancy. These are all skills that the students of this study should be able to acquire as well after their participation in the boat building project of this study. 


\section{Chapter 3: Methods}

Overview

In this study, self-efficacy is defined by six constructs: Motivation, Course Skills, Confidence, Teamwork, Resilience, and Problem Solving. This study evaluated the effectiveness of a PBL in-school program. The created curriculum has common elements in established theories in Project Based Learning, Cognitive Motivation, and Selfefficacy. The independent variable of this study was the curriculum developed by the Wind and Oar Boat School that has aligned their curriculum with the afore mentioned theories. The dependent variables within this study were observations of the participants' Motivation, Course Skills, Confidence, Teamwork, Resilience, and Problem Solving. The researcher measured the students' self-efficacy through the constructs of Motivation, Course Skills, Confidence, Teamwork, Resilience, and Problem Solving by administering a self-efficacy survey, Student interviews, and making observations of the students' experiences during each class period throughout the six-week course. The observations were recorded through notes of the informal observations of students' experiences during each class. The observations and interviews were used to evaluate the responses of the students as compared to their responses on the survey instrument.

The participants in this research project included 14 males and six female students in Grades 10 to 12 from Malbec Community High School, which is a small nontraditional high school in the Duckville School district a suburb of Portland Oregon. As part of Duckville Public School’s enrollment summary Malbec, Community High serves approximately 200 students in grades 9-12. The school serves students from all areas of the Duckville School District. Malbec Community High School is an alternative school 
where about $80 \%$ of students at Community School receive free or reduced meal benefits. The racial and ethnic composition of Malbec Community School is 55\% Hispanic, 2\% Asian, 5\% Black/African American, 2\% Multiracial and 36\% White, 49\% of the were listed as students with disabilities, at the school, there are three different languages spoken prominently in the school. Seven percent of students are enrolled in English as a Second Language program. These demographics vary from the demographics of the rest of the school district which has the following demographic breakdown: 24\% Hispanic, 15\% Asian, 3\% Black/African American, 7\% Multiracial and 50\% White respectively.

Table 1. Student Demographics

\begin{tabular}{|l|l|l|l|}
\hline Demographic & Number & Percent & School Attendance Percentage \\
\hline Gender & 6 & 30 & N/A \\
\hline Female & 14 & 70 & N/A \\
\hline Male & 11 & 55 & 88.2 \\
\hline Race/Ethnicity* & $\begin{array}{l}\text { Hispanic or } \\
\text { Latino }\end{array}$ & 5 & 90.6 \\
\hline $\begin{array}{l}\text { Black or } \\
\text { African } \\
\text { American }\end{array}$ & 1 & 40 & 88.4 \\
\hline White & 8 & \multicolumn{2}{|l|}{} \\
\hline Total & 20 & $\begin{array}{l}\text { * More than one race" and "unknown or not reported" "races" that were not represented } \\
\text { in the study are not shown. }\end{array}$ \\
\hline
\end{tabular}

The program was part of the 2016 spring term of the Wind \& Oar Boat curriculum instructed by the staff of the Wind \& Oar Boat School in cooperation with the administration of the Malbec Community High School. The participants in the study were students that were attending the Wind \& Oar Boat curriculum offered at Malbec Community High School, who had volunteered to participate this study. The overall number of students who took part in the Wind \& Oar Boat curriculum totaled just under 60 students, with 33\% participation rate in the study. 


\section{Study Measures}

The researcher was a participant observer. The term participant observer refers to a method of qualitative fieldwork frequently used in sociology, and other social science disciplines. The participant observer both observes and is actively participating in the practices of the study (Merriam, 2009). The role of a participant observer is to gain a more intimate, comprehensive, and nuanced understanding of the participants in the study. Participation can increase trust from research subjects, which leads to greater access to members, and deeper insight because of a more personal experience.

As well as being a participating observer the researcher took notes, interviewed students, and administered a retrospective pre- then post- design academic self-efficacy assessment. The self-efficacy assessment survey consisted of 29 questions that encompassed the six constructs of motivation, course skills, confidence, teamwork, resilience, and problem-solving that were utilized to ascertain student self-efficacy after participation the in the PBL activity of building a boat. Furthermore, all participating students were selected for interviews about this assessment and their connections to the program. The afore mentioned assessment tools were utilized to give an account of the student experience during their participation in the program the researcher selected five students that represented the other students of the program.

The narratives detail the experiences of the different participant students from the beginning of their participation in the program; and in some cases, the researcher had additional information to glimpse into their lives after the program. The narrative was used to consider the changes in self-efficacy of the students that participated in the Wind and Oar Boat school’s PBL project. 
To take advantage of the strengths of quantitative and qualitative perspectives and mitigate the limitations of each the researcher utilized a mixed method quasiexperimental research design (Ercikan \& Roth, 2009). The overall intention was to obtain a complete understanding of students' responses to the curriculum than would be provided by either approach alone. This study documented variations in student selfevaluations and behaviors using the retrospective pre- post-test evaluation (Stevens, 1999). Students were given the survey after their completion of the course. The retrospective post- then pre-test design is not unlike the typical pretest-posttests (Pratt, McGuigan, \& Katzev, 2000). Pratt, McGuigan, \& Katzev claim that this tool is specifically useful for evaluating the impact of extensive cooperative extension studies which are very similar in design to PBL activities in that they are group based in nature. Both ask participants to report actual changes in behavior or self-perceived attitudes. The principal difference is that the retrospective pre- post-test evaluation is administered only once. After the experience, participants are asked to share the knowledge or attitudes they had toward an experience at the outset. Additionally, in the same questionnaire, participants were asked to share the knowledge or attitudes they had toward their participation following their experience. The retrospective pre- then post-test is like a traditional pretest/posttest evaluation method. However, the retrospective pretest provides the participant with a "baseline" level of knowledge. Specifically, when the participant is asked to respond to a question about how much they know about a subject after they have some basic awareness of the issue itself, they are better able to reflect accurately on the degree of change in knowledge or attitude. Furthermore, respondents will often overestimate their level of knowledge on a subject when using the traditional pretest- 
posttest (Pratt et al., 2000, Davis, 2003). With the retrospective pretest/posttest, method, the participants can learn how much they know about a subject before responding to a questionnaire.

The retrospective pre- post-test can also be more accurate because it answers in the same frame of reference as a post-test. Thereby reducing the chances that respondents score better on a post-test because of their exposure to the pretest. It is also referred to as “response-shift bias” in self-report pretest/posttest designs and can be minimized through use of the retrospective pretest design per (Pratt et al., 2000, Davis, 2003)

When students use the various tools, and follow the procedures of the boat building process, they learn that there are multiple aspects of the build that affect skills they can use in other courses. Those skills include the physics of hull design, boat weight, and displacement, to the botany behind wood choices, to the chemical makeup of the paint used on boats, a knowledge of scientific inquiry and principles benefits the design, and function of a wooden boat. Finally, the elements of design, function and aesthetics are woven together in the building of a wooden boat. These skills are made available to the participating students of this program.

The Wind and Oar Boat Program

The program was a six-week in-school course called Malbec Community High School 2016 boat building class with Wind \& Oar Boat School. It was developed to integrate the academic competencies that are found in boat building, as well as challenge students' craftsmanship, teamwork, and problem-solving skills. This program brings greater academic rigor than regular shop classes offered at other schools, due to the 
complexity of the boat design and the program's time intensive format, and in so doing, has a greater and lasting impact. Building a wooden boat is an innovative and unique platform for exploring the importance of motivation, confidence, teamwork, resilience, and problem-solving skills. From concept and design, to reviewing plans, scaling up materials, shaping parts, utilizing hand and power tools, was an opportunity to teach and reinforce motivation, confidence, teamwork, resilience, and problem-solving skills that the students can take with them into related science, technology, engineering and math skills used in the building of the boat.

During this course the researcher assumed the role or participant observer, assisting the other facilitators in the day to day flow of the building process. Primarily the researcher was there to maintain the safety of the students while the other instructors were otherwise occupied with other students. At times the researcher was required to assist in the instruction of the different build side projects, but for the most part, the researcher was an observer letting the facilitators lead the discussions and building process. The boat building course was scheduled five days a week for two school class periods during the typical school day for six weeks. During the six-week course, the students all participated in tool familiarization before beginning to work on the boat. While learning about the tools and vocabulary of the process the student also reviewed measurements, fractions, scaling, and geometry skills that are used in boat building. Additional activities combined learning tasks that included problem-solving, collaborative design conceptualization, project planning and teamwork to create the numerous parts needed in the project. 
The intervention focused on student-driven exploration by utilizing hands-on woodworking experiences while making math and science relevant. Students are provided a space to develop critical thinking, team building, and leadership skills, all of which are important aspects of self-efficacy. The facilitators guide the students when needed through difficult talks and remind them of the necessary skills that need to be implemented to accomplish the task at hand. However, the students were free to make mistakes and were encouraged to try new ideas. This was achieved through reading plans, developing a course of action, anticipating shortfalls or bottlenecks, and finally, executing the process as a team. The tools used by the students included traditional hand woodworking tools as well as modern shop tools. Intervention Implementation

The boat building course began in December of 2015 during the third wheel, or term, of the school year at Malbec Community High School, and ran through the sixth and final wheel of the school year. Each wheel lasts six weeks, and the boat class took place from 9:00 to 11:35 A.M. during the second and third class periods of the school day respectively. For the first two wheels, the researcher acted as a facilitator and passive observer. No research was collected during these wheels, and the observations that were made were only for guidance in the assessment formulation and the creation of an observation protocol that was utilized in the final two wheels to collect observations. Consent forms were sent home with the participants during the first week of the last wheel. The consent forms were collected throughout the term by the researcher. 
Wheel One

The students were introduced to the various tools of the workshop and the safety rules that would be adhered to for the duration of the program. The schedule of the build and the different steps that would be involved were discussed, and the input of the students was encouraged. This schedule demonstrates to the students how they can apply classroom content to realistic phenomena. After initial safety guidelines had been established the design of the boat was discussed and the process of 'lofting' was introduced to the students. Lofting is the process of blowing up the relatively small-scale plans from an architect into full-size plans.

The students began to draw out three grids onto a life-sized whiteboard, one for each standard view of the boat that the students find in the boat's plans. The three standard views are the body plan, profile, and half-breadth view. The instructors emphasized the importance to accuracy and attention to detail throughout this process as well as basic measurements, ratios, and geometric theorems. In conjunction with these concepts communication and problem-solving practices that enabled the students to learn through trial and error. They learned that if their perpendicular line is just 0.005 degrees off, then it will be almost $1 / 4$ " off at the end of their 4 ' perpendicular lines that they drew on the lofting board. The process was repetitive and required the students to measure various lengths and then scale these lengths into full-size lengths and then transfer them to the lofting board. The repetition of reading plans and scaling up measurements was an opportunity to teach and reinforce the engineering and math skills used in the boat building process. Only two of the students of this study participated in the build from the 
first wheel through the last wheel. The process of lofting consumed the entire six-week wheel.

Wheel Two

The second Wheel the students followed the same schedule as the first in that they had a week of tool and safety orientation before their participation in the boat building process. This wheel focused on the construction of the support structure used to hold the boat during the initial building process. The students followed the guidance of the facilitators on the numerous side projects that were required to prepare for the actual construction of the boat. This wheel saw many new faces and only a couple return students.

Wheel Three

Wheel three the students started making molds of the different parts of the boat from the lofted boat plans drawn out in the first wheel. This wheel saw a dramatic change in students and data collection officially began in this wheel as well. The first week of wheel three began with handing out permission forms and the basic tool and safety orientation that had occurred in the preceding wheels. My role switched from participant instructor to that of participant observer, no longer taking an active role as an instructor. With the support structures in place from the previous wheels, the process of creating the myriad pieces needed to put the boat began in earnest. The instructors guided the students through the engineering and math skills used in creating the many smaller pieces that would later be used to assemble the boat. The keel and transom of the boat were assembled, and the molds for the planks were created. 
Wheel Four

The fourth and final wheel had another high turnover of students with only four returning from any of the earlier wheels. Once again my role was that of participant observer assisting only when an extra pair of hands were needed for safety reasons. This wheel was the culmination of the previous efforts from earlier students. The final assembly of the boat from the pieces that were fabricated by earlier students occurred at a rapid pace. The shape of the boat changed daily, and the more the students repeated an action on the boat they took less and less time to accomplish the same task day by day. The instructors continued to emphasize the importance of teamwork, communication, and attention to detail in the final stages of the project.

Self-efficacy Assessment

The instrument used to assess the students' self-efficacy was developed by the researcher from a list of questions that had been designed and refined over time by a group of fellow researchers from Portland State University, using Bandura's theory of self-efficacy to examine the relation between the learning activity and students’ motivation and behavior (See Appendix 1) Student scales assess 1) Cognitive Motivation; 2) Course Skills; 3) Confidence; 4) Teamwork; 5) Resilience; and 6) Problem Solving. Items on the student scales are anchored at 1 = "Strongly Disagree,” 2 = " Disagree,” $3=$ “Neutral,” 4 = “Agree,” and 5 = "Strongly Agree." The survey instrument was evaluated by the researcher and researchers from his cohort, to compute the Cronbach alpha for the correlation of the questions to the constructs of self-efficacy. The calculated alpha for the survey was $\alpha=.95$. 
The survey was given to the students in class on the penultimate day of the wheel the students participated in, followed up the next day with interviews. The student surveys were administered by the researcher in the students' regular classroom. Students were told that the survey is not a test and that there are no right or wrong answers. The survey was confidential, and student responses could not be attributed back to any individual student. Also, before beginning the survey, an explanation as to why the researcher asked similar sounding questions is provided to students (i.e., to measure a construct accurately the researcher inquired about similar items in several different ways to make sure that the researcher understood what the students were telling him). A sample question was used at the beginning of the survey to demonstrate how to the Likert scale. All instructions and each item are read aloud to students. The researcher avoided sessions of more than 40 minutes in length.

Table 2. Observations

\begin{tabular}{|l|l|l|l|l|}
\hline Date & $\begin{array}{l}\text { Construct of } \\
\text { Self efficacy }\end{array}$ & Observations & $\begin{array}{c}\text { Numb } \\
\text { er of } \\
\text { studen } \\
\text { ts }\end{array}$ & $\begin{array}{l}\text { Positive/ } \\
\text { negative }\end{array}$ \\
\hline 14-Apr & $\begin{array}{l}\text { Course skills, } \\
\text { motivation } \\
\text { confidence }\end{array}$ & $\begin{array}{l}\text { Three students continued working on planks } \\
\text { though obviously bored they got to work } \\
\text { today with little prompting. They only } \\
\text { needed minimal prime on the basic } \\
\text { attractions were first time with the students } \\
\text { the whole process is not needed to be } \\
\text { explained to them all times }\end{array}$ & 3 & Positive \\
\hline 14-Apr & $\begin{array}{l}\text { Motivation, } \\
\text { course skills, } \\
\text { confidence, } \\
\text { teamwork, } \\
\text { resilience, } \\
\text { problem- } \\
\text { solving }\end{array}$ & $\begin{array}{l}\text { Student demonstrates real skill with } \\
\text { chiseling work. His main complaint was that } \\
\text { only two other students can do the work in a } \\
\text { usable manner wants to work on other } \\
\text { projects he feels stuck doing the same thing } \\
\text { every day after day. Researcher comment: } \\
\text { progress has been made with this student } \\
\text { after so many days doing the same thing and } \\
\text { wanting relief he finds another student and } \\
\text { sits down to teach them how he does it the } \\
\text { so he can move on to different project. }\end{array}$ & 2 & Positive \\
\hline
\end{tabular}




\begin{tabular}{|c|c|c|c|c|}
\hline 15-Apr & Resilience & $\begin{array}{l}\text { Female student complains about working on } \\
\text { the same project for two weeks however she } \\
\text { comes to school every day and works on it } \\
\text { today is the first day she complained about } \\
\text { working on the same project }\end{array}$ & 1 & Negative \\
\hline 15-Apr & $\begin{array}{l}\text { Motivation, } \\
\text { teamwork, } \\
\text { problem- } \\
\text { solving, } \\
\text { course skills }\end{array}$ & $\begin{array}{l}\text { I'm only here today so that I can finish the } \\
\text { cans that I started and I knew the others } \\
\text { guys were going to be gone. Research } \\
\text { comment: this student finds at first but once } \\
\text { she starts a project efficient to the end he } \\
\text { takes ownership of products once he starts } \\
\text { only problem is he resist starting most tasks } \\
\text { given to. }\end{array}$ & 1 & Positive/Negative \\
\hline 15-Apr & $\begin{array}{l}\text { Motivation, } \\
\text { course skills, } \\
\text { confidence, } \\
\text { teamwork, } \\
\text { resilience, }\end{array}$ & $\begin{array}{l}\text { Student began wheel very withdrawn had to } \\
\text { be guided step-by-step through every } \\
\text { process, today he and his partner were given } \\
\text { a project he said "I got this, it can be done } \\
\text { by one person, so he can go work on } \\
\text { something else or help someone else" }\end{array}$ & 2 & Positive \\
\hline 18-Apr & $\begin{array}{l}\text { Motivation, } \\
\text { teamwork, } \\
\text { confidence, } \\
\text { course skills }\end{array}$ & $\begin{array}{l}\text { Two students went straight to work on the } \\
\text { oars that they had been working on last } \\
\text { week. The direction or input was needed the } \\
\text { instructor went over to see if they wanted } \\
\text { any clarification both said no we got this } \\
\text { this these are our words so it's going to be } \\
\text { done right. }\end{array}$ & 2 & Positive \\
\hline 18-Apr & $\begin{array}{l}\text { Motivation, } \\
\text { confidence, } \\
\text { teamwork, } \\
\text { resilience, } \\
\text { problem- } \\
\text { solving }\end{array}$ & $\begin{array}{l}\text { Three students were making clink forms } \\
\text { found error in their forms without direction } \\
\text { went back and started start to correct the } \\
\text { mistake finished blanks before and of class }\end{array}$ & 3 & Positive \\
\hline 20-Apr & $\begin{array}{l}\text { Motivation, } \\
\text { competence, } \\
\text { problem- } \\
\text { solving }\end{array}$ & $\begin{array}{l}\text { Student came into class today and asked } \\
\text { what can you give me today I want this boat } \\
\text { done. Same student went on his own to } \\
\text { work on a bench that was wobbly three } \\
\text { other students assisted in fixing the bench. }\end{array}$ & 4 & Positive \\
\hline 20-Apr & Motivation & $\begin{array}{l}\text { I like being here more than any other part of } \\
\text { this school day }\end{array}$ & 1 & Positive \\
\hline 21-Apr & $\begin{array}{l}\text { Teamwork, } \\
\text { course skills }\end{array}$ & $\begin{array}{l}\text { Two normally very talkative students are } \\
\text { working on the orders for the boat both are } \\
\text { planning each step together and maintaining } \\
\text { their efforts on task both are not going to } \\
\text { teachers for direction for information, only } \\
\text { giving instructors updates as to what they } \\
\text { are doing. }\end{array}$ & 2 & Positive \\
\hline
\end{tabular}




\begin{tabular}{|c|c|c|c|c|}
\hline 21-Apr & $\begin{array}{l}\text { Motivation, } \\
\text { teamwork, } \\
\text { Resilience }\end{array}$ & $\begin{array}{l}\text { Student with broken thumb asked } \\
\text { instructors I want to help where I can even } \\
\text { with my thumb the way it is. }\end{array}$ & 1 & Positive \\
\hline 21-Apr & $\begin{array}{l}\text { Course skills, } \\
\text { problem- } \\
\text { solving }\end{array}$ & $\begin{array}{l}\text { Student with emotional issues stated what } \\
\text { I'm using the plane I can stay focused and } \\
\text { my problems don't bug my thoughts as } \\
\text { much. }\end{array}$ & 1 & Positive \\
\hline 21-Apr & $\begin{array}{l}\text { Problem } \\
\text { solving, } \\
\text { motivation, } \\
\text { course skills, } \\
\text { teamwork }\end{array}$ & $\begin{array}{l}\text { Student asked instructor how to fix one of } \\
\text { the braces on the strong back and the } \\
\text { instructor informed how to do it student and } \\
\text { fixed it out being asked to work on it. } \\
\text { Research comment: this student usually } \\
\text { must be prodded to keep working during } \\
\text { this week he has made more effort to find } \\
\text { tasks to work on. }\end{array}$ & 1 & Positive \\
\hline 21-Apr & $\begin{array}{l}\text { Course skills, } \\
\text { confidence, } \\
\text { motivation }\end{array}$ & $\begin{array}{l}\text { While working on the handle for the } \\
\text { cabinets student was giving the parameters } \\
\text { for the handles she sat down and designed it } \\
\text { without the assistance of an instructor didn't } \\
\text { she did not ask for directions or guidance. }\end{array}$ & 1 & Positive \\
\hline 21-Apr & $\begin{array}{l}\text { Teamwork, } \\
\text { motivation, } \\
\text { problem- } \\
\text { solving }\end{array}$ & $\begin{array}{l}\text { While working on site project when student } \\
\text { notices three other students talking and not } \\
\text { working and says talking is good but keep } \\
\text { working }\end{array}$ & 4 & Positive/Negative \\
\hline 4-May & $\begin{array}{l}\text { Course skills, } \\
\text { confidence, } \\
\text { problem- } \\
\text { solving }\end{array}$ & $\begin{array}{l}\text { Student comes into class begins to work on } \\
\text { a piece, notices that the tool is dull, without } \\
\text { guidance student disassembles tool takes } \\
\text { part that needs to be sharpened to } \\
\text { sharpening stone sharpens tool, reassembles } \\
\text { it, goes back to work student comment I } \\
\text { take my time to make sure everything is } \\
\text { done correctly and I only came back this } \\
\text { wheel because I started the boat and I } \\
\text { wanted to be here when it was finished. }\end{array}$ & 1 & Positive \\
\hline 4-May & Confidence & $\begin{array}{l}\text { Researcher comment: the student in the } \\
\text { above observation has made large changes } \\
\text { in confidence the tool that heated } \\
\text { disassembled and fixed without being asked } \\
\text { to do it had a similar experience happened } \\
\text { on this first day of class and his exact quote } \\
\text { was I want to test out I'm scared when he } \\
\text { was asked to touch the hand plane. }\end{array}$ & 1 & Positive \\
\hline 5-May & $\begin{array}{l}\text { Motivation, } \\
\text { course skills, } \\
\text { confidence }\end{array}$ & $\begin{array}{l}\text { The student was presented a new tool } \\
\text { student stated oh I want to use it first! Give } \\
\text { it to me give it to me! }\end{array}$ & 1 & Positive \\
\hline
\end{tabular}




\begin{tabular}{|c|c|c|c|c|}
\hline 5-May & $\begin{array}{l}\text { Motivation, } \\
\text { confidence, } \\
\text { resilience, } \\
\text { problem- } \\
\text { solving }\end{array}$ & $\begin{array}{l}\text { Conversation between student and } \\
\text { counselor: teacher asked student is the boat } \\
\text { going to be ready before the school student } \\
\text { replies I work weekends and into the } \\
\text { summer to get this finished! }\end{array}$ & 1 & Positive \\
\hline 5-May & $\begin{array}{l}\text { Core skills, } \\
\text { problem- } \\
\text { solving, } \\
\text { teamwork }\end{array}$ & $\begin{array}{l}\text { Researcher comment: female student notices } \\
\text { new students about to use would that is set } \\
\text { aside for the keel she stated, they should } \\
\text { practice on scrap wood first, I don't want my } \\
\text { boat messed up! }\end{array}$ & 4 & Positive \\
\hline 5-May & $\begin{array}{l}\text { Problem } \\
\text { solving, } \\
\text { course skills }\end{array}$ & $\begin{array}{l}\text { Conversation lead instructor and student } \\
\text { asks how far do I have to go on this } \\
\text { instructor just down to this point student } \\
\text { okay got it. If I got this should I keep going } \\
\text { on this line? Instructor yes. Student okay. }\end{array}$ & 1 & Positive \\
\hline 5-May & $\begin{array}{l}\text { Teamwork, } \\
\text { motivation }\end{array}$ & $\begin{array}{l}\text { I'm done with my project can help you guys } \\
\text { with yours? }\end{array}$ & 3 & Positive \\
\hline 6-May & $\begin{array}{l}\text { Problem } \\
\text { solving }\end{array}$ & $\begin{array}{l}\text { Student was having problems planning or } \\
\text { due to lack of support she searched around } \\
\text { and found extra pieces of wood and jerry- } \\
\text { rigged a support so that she could continue } \\
\text { planning without having someone else assist } \\
\text { her. }\end{array}$ & 1 & Positive \\
\hline 6-May & Motivation & $\begin{array}{l}\text { Student comment: I'm learning something } \\
\text { new every day while working on this boat. }\end{array}$ & 1 & Positive \\
\hline $\begin{array}{l}\text { 11- } \\
\text { May }\end{array}$ & $\begin{array}{l}\text { World vision, } \\
\text { course skills, } \\
\text { confidence, } \\
\text { resilience }\end{array}$ & $\begin{array}{l}\text { Delete student is getting short directions and } \\
\text { gets to work by himself after asking small } \\
\text { questions for clarification, student finishes } \\
\text { project without further direction. }\end{array}$ & 1 & Positive \\
\hline $\begin{array}{l}\text { 11- } \\
\text { May }\end{array}$ & $\begin{array}{l}\text { Motivation, } \\
\text { teamwork, } \\
\text { confidence }\end{array}$ & $\begin{array}{l}\text { Female student makes comment let me } \\
\text { make the holes. You guys usually get to do } \\
\text { this it's my turn now. }\end{array}$ & 3 & Positive \\
\hline $\begin{array}{l}\text { 12- } \\
\text { May }\end{array}$ & $\begin{array}{l}\text { Teamwork, } \\
\text { resilience }\end{array}$ & $\begin{array}{l}\text { Three students working quietly with no } \\
\text { outside guidance on steam box. }\end{array}$ & 3 & Positive \\
\hline $\begin{array}{l}\text { 18- } \\
\text { May }\end{array}$ & $\begin{array}{l}\text { Confidence, } \\
\text { teamwork, } \\
\text { problem- } \\
\text { solving }\end{array}$ & $\begin{array}{l}\text { Three students organize and plan jobs for } \\
\text { working on planks. }\end{array}$ & 3 & Positive \\
\hline
\end{tabular}




\begin{tabular}{|c|c|c|c|c|}
\hline $\begin{array}{l}\text { 18- } \\
\text { May }\end{array}$ & $\begin{array}{l}\text { Resilience, } \\
\text { teamwork }\end{array}$ & $\begin{array}{l}\text { Three students work outside in the sun to } \\
\text { clean planks down to } 1 / 2 \text { inch. When } \\
\text { offered to come inside students stated we } \\
\text { want this done today if we take a break it'll } \\
\text { take us longer to finish. }\end{array}$ & 3 & Positive \\
\hline $\begin{array}{l}\text { 18- } \\
\text { May }\end{array}$ & $\begin{array}{l}\text { Motivation, } \\
\text { teamwork }\end{array}$ & $\begin{array}{l}\text { Two students finish individual projects early } \\
\text { decided to clean up their area but then } \\
\text { proceeded to clean up. Around students that } \\
\text { are still working when asked why they said } \\
\text { my area is the only place that's dirty we all } \\
\text { work here. }\end{array}$ & 2 & Positive \\
\hline May 19 & $\begin{array}{l}\text { Course Skills, } \\
\text { teamwork, } \\
\text { problem- } \\
\text { solving }\end{array}$ & $\begin{array}{l}\text { Student double checking each other's } \\
\text { measurements without complaints quotation } \\
\text { the smell of better to double check that you } \\
\text { wrote board }\end{array}$ & 2 & Positive \\
\hline $\begin{array}{l}\text { 23- } \\
\text { May }\end{array}$ & $\begin{array}{l}\text { Course skills, } \\
\text { teamwork, } \\
\text { problem- } \\
\text { solving } \\
\end{array}$ & $\begin{array}{l}\text { Did you get a level? Let me check because I } \\
\text { don't want to mess this up. This was done } \\
\text { while putting a level on bottom edge of } \\
\text { plank }\end{array}$ & 2 & Positive \\
\hline $\begin{array}{l}\text { 23- } \\
\text { May }\end{array}$ & $\begin{array}{l}\text { Motivation, } \\
\text { teamwork }\end{array}$ & $\begin{array}{l}\text { "Can I hammer that? I want to be a part of } \\
\text { this job also. }\end{array}$ & 3 & Positive \\
\hline $\begin{array}{l}\text { 23- } \\
\text { May }\end{array}$ & $\begin{array}{l}\text { Course skills, } \\
\text { confidence, } \\
\text { resilience, } \\
\text { problem- } \\
\text { solving }\end{array}$ & $\begin{array}{l}\text { I'm going if it's little because I want this } \\
\text { done right the first time. }\end{array}$ & 1 & Positive \\
\hline $\begin{array}{l}\text { 24- } \\
\text { May }\end{array}$ & $\begin{array}{l}\text { Teamwork, } \\
\text { resilience, } \\
\text { motivation }\end{array}$ & $\begin{array}{l}\text { You're here! I know that I'm late but I } \\
\text { wanted to be here for the class even though } \\
\text { I wanted to sleep }\end{array}$ & 2 & Positive \\
\hline $\begin{array}{l}\text { 24- } \\
\text { May }\end{array}$ & $\begin{array}{l}\text { Motivation, } \\
\text { like core } \\
\text { skills, } \\
\text { teamwork, } \\
\text { problem- } \\
\text { solving }\end{array}$ & $\begin{array}{l}\text { Five students came to work on the boat for } \\
\text { four hours on Saturday because the boat was } \\
\text { behind schedule and they wanted to get } \\
\text { back on track. }\end{array}$ & 5 & Positive \\
\hline $\begin{array}{l}\text { 25- } \\
\text { May }\end{array}$ & $\begin{array}{l}\text { Core skills, } \\
\text { teamwork }\end{array}$ & $\begin{array}{l}\text { Two students actively working on } \\
\text { measuring planks and aligning planks for } \\
\text { attachment take small break to catch third } \\
\text { student of that came to class late all three } \\
\text { students continue working and finished the } \\
\text { planks they were working on before class }\end{array}$ & 3 & Positive \\
\hline 6-Jun & $\begin{array}{l}\text { Motivation, } \\
\text { teamwork }\end{array}$ & $\begin{array}{l}\text { When asked, who wants to trace out the last } \\
\text { blank half the class jumped up to do it }\end{array}$ & 6 & Positive \\
\hline 7-Jun & $\begin{array}{l}\text { Confidence, } \\
\text { course skills }\end{array}$ & $\begin{array}{l}\text { When presented task the riveting one } \\
\text { student states on the program riveting don't } \\
\text { give him job I got. }\end{array}$ & 2 & Positive \\
\hline 8-Jun & $\begin{array}{l}\text { Problem- } \\
\text { solving, } \\
\text { teamwork, or } \\
\text { skills }\end{array}$ & $\begin{array}{l}\text { Students notice that some of the rivets were } \\
\text { not aligned up correctly on all the planks } \\
\text { sought advice as to how to fix and } \\
\text { proceeded to correct the problem. }\end{array}$ & 3 & Positive \\
\hline
\end{tabular}




\begin{tabular}{|l|l|l|c|l|}
\hline 9-Jun & Resilience & $\begin{array}{l}\text { Students work on riveting again today small } \\
\text { complaints about repetition of the task but } \\
\text { continued to work even though they were } \\
\text { bored. }\end{array}$ & 8 & Negative \\
\hline 10-Jun & $\begin{array}{l}\text { Motivation, } \\
\text { resilience, } \\
\text { teamwork }\end{array}$ & $\begin{array}{l}\text { All planks are riveted to the boat has been } \\
\text { flipped work has commenced on the internal } \\
\text { side of the boat. Students are excited about } \\
\text { progress some still complain about the time } \\
\text { it takes to finish but work as a team to } \\
\text { accomplish task at hand. }\end{array}$ & 8 & Positive/negative \\
\hline 10-Jun & $\begin{array}{l}\text { Resilience, } \\
\text { motivation }\end{array}$ & $\begin{array}{l}\text { Today was last day for seniors, some seniors } \\
\text { came back to work on boat even though } \\
\text { they were free to leave }\end{array}$ & 3 & Positive \\
\hline
\end{tabular}

Interviews

Interviews often followed individual conversational threads that emerged from the subjects' thoughts, attitudes; the order of questions was altered somewhat after the first few interviews to improve questions and focus on more productive lines of inquiry. The interviews were used to in conjunction with the survey data and researcher observations to formulate a comprehensive analysis of the student experience in the program.

After analyzing the survey data, the researcher noticed that some of the students were not demonstrating changes in motivation, which conflicted with observations made on the same students daily. However, in the interviews, most of the students acknowledged that they were noticeably more motivated to come to school as well as putting more effort into their schoolwork.

\section{Student Narratives}

The researcher selected five students that represented the various students of the program. The narratives detail the experiences of the different participant students from the beginning of their participation in the program, and in some cases, the researcher had 
additional information to glimpse into their lives after the program. The narrative was used to give a more in-depth look, into the change of self-efficacy in the students that participated in the Wind and Oar Boat school's PBL project. used to give a more indepth look, into the change of self-efficacy in the students that participated in the Wind and Oar Boat school's PBL project. 
Chapter 4: Results

Table 3. Wind and Oar Wheel Schedule

\begin{tabular}{|l|l|l|l|l|l|l|}
\hline Wheel & Main task & Attendance & Dates & $\begin{array}{l}\text { \# of } \\
\text { students }\end{array}$ & $\begin{array}{l}\text { Instructor/student } \\
\text { interactions }\end{array}$ & Gender \\
\hline $\begin{array}{l}\text { Wheel } \\
1\end{array}$ & Lofting & $91 \%$ & $\begin{array}{l}01 \text { Dec15 } \\
- \\
29 J a n 16\end{array}$ & 15 & $\begin{array}{l}\text { Lecture/ Small } \\
\text { groups/ one on one }\end{array}$ & $\begin{array}{l}14 \text { Male } \\
1 \\
\text { Female }\end{array}$ \\
\hline $\begin{array}{l}\text { Wheel } \\
2\end{array}$ & $\begin{array}{l}\text { Strongback/ } \\
\text { Work } \\
\text { benches }\end{array}$ & $84.4 \%$ & $\begin{array}{l}01 \mathrm{Feb} 16 \\
- \\
11 \text { Mar16 }\end{array}$ & 17 & $\begin{array}{l}\text { Small groups/ one } \\
\text { on one }\end{array}$ & $\begin{array}{l}\text { 13 Male } \\
4 \\
\text { Female }\end{array}$ \\
\hline $\begin{array}{l}\text { Wheel } \\
3\end{array}$ & $\begin{array}{l}\text { Chiseling } \\
\text { Planks }\end{array}$ & $85.6 \%$ & $\begin{array}{l}14 \text { Mar16 } \\
- \\
\text { 29Apr16 }\end{array}$ & 20 & $\begin{array}{l}\text { Small groups/ one } \\
\text { on one }\end{array}$ & $\begin{array}{l}\text { 15 Male } \\
5 \\
\text { Female }\end{array}$ \\
\hline $\begin{array}{l}\text { Wheel } \\
\text { Riveting }\end{array}$ & $\begin{array}{l}\text { Frames } \\
\text { 02May16 }\end{array}$ & 20 & $\begin{array}{l}\text { Small groups/ one } \\
\text { on one }\end{array}$ & $\begin{array}{l}\text { 15 Male } \\
5 \\
\text { Female }\end{array}$ \\
\hline
\end{tabular}

The Wind and Oar Boat course have students building a full-sized water capable vessel from drawings, utilizing an innovative and unique platform for exploring the importance of self-efficacy and motivational resilience. Each step in the construction of a boat, from concept design, reviewing plans, scaling up materials, fitting and shaping parts, mastering tools, is an opportunity to teach and reinforce the self-efficacy and motivational resilience, as well as the Science, Technology, Engineering, Math (STEM) skills and artistic skills used in the boat building process.

In wheel one, the students were creating the full-scale blueprint of the boat. This process is called “Lofting.” This process required the students to work in small groups with an occasional one-on-one with the instructor. There were additional lecture style classes to introduce new aspects of the Lofting to the whole class to facilitate breadth of 
student understanding. The instructors were constantly roving among the students to answer questions and to check on the student work as needed.

Wheel two the students built the Strongback, which is simply the temporary jig used to hold the forms and stems in place while creating the hull of a boat. This process required the students to work in small groups with the occasional one-on-one with the instructor. The instructors were constantly roving among the students to answer questions and to check on the student work as needed.

Wheel three the students began chiseling the rabbet into the Keel and Stem. The rabbet is a groove for planks to butt up against. The rabbet must be accurately cut to form a tight seal. The rabbet for the boat runs down both sides of the stem and continues along the keel to the stern. In addition to cutting the rabbet, the students were making molds for the different shaped planks that would be attached to the next wheel. This process required the students to work in small groups with the occasional one-on-one with the instructor. The instructors were constantly roving among the students to answer questions and to check on the student work as needed.

In the fourth and final wheel, the students began attaching the planks that were made in the previous wheel. To accomplish this, the students used brass rivets and worked in small two to three person teams to attach each plank to the boat after steaming the ends to allow for easier bending of the planks. After all the planks were attached the students then proceeded to make and attach the ribs for the interior of the boat. This process required the students to work in small groups with the occasional one-on-one 
with the instructor. The instructors were constantly roving among the students to answer questions and to check on the student work as needed.

The classroom observations, interviews and survey questions used to assess the students' self-efficacy were developed by the researcher using Bandura's theory of selfefficacy to examine the relation between the learning activity and students' behavior and motivation. These self-efficacy constructs were Motivation, Course Skills, Confidence, Teamwork, Resilience and Problem Solving. These constructs were used as means to assess whether the program answered the researcher's question of "How the participation in a project based learning activity of building a boat affect the academic identity and motivational resilience "self-efficacy" of high school students'.

The researcher analyzed both the qualitative and quantitative data collected as they applied to the constructs of self-efficacy. After analyzing the survey data, the researcher noticed that some of the students were not demonstrating changes in motivation, which conflicted with observations made on the same students daily. However, in the interviews, most of the students acknowledged that they were noticeably more motivated to come to school as well as putting more effort into their schoolwork.

During the interviews, the concept of self-efficacy was described once again. Many students described positive observations of self-efficacy by the end of the program. Most participants reported feeling that they were successful in the program, overcoming fears of tools and the unknown of building a boat and that they enjoyed the experience. Some participants showed low self-efficacy related to school performance. When students were asked about their success in the program, many felt that they were more 
successful in the program as opposed to other classes. However, other students felt that the success they felt in the program transferred outside of the class and into other classes. When participants described why they felt successful, the responses fell into four of the six constructs repeatedly: Confidence, Team Work, Resilience, and Problem Solving. This follows the results of the survey that they could apply the skills they had learned in the course outside the class.

Many stated that they felt more confident in their abilities to measure and one female student stated: "I can go home and fix anything that is broken without having to ask my dad or wait on my brothers to do it for me.” This same student had zero change in any of her motivation or confidence questions in her responses on the survey. Therefore, in her case the interview gave a better picture of the interviews gave the students a chance to express their opinions on the course and clarify their responses on the survey if they chose to divulge information that was not within the structured questions of the interview process. Not all the interviews demonstrated greater insight into the survey instrument, but enough reinforced the results of the survey that they confirmed the results that were collected.

Negative statements made during the interviews were consistent with the senior students. Those being that they felt that they did not see a dramatic difference in their motivation related to the course. The number one reason that they all said was that they were about to graduate and that they would come to class only to finish the final requirement to graduate in a couple of weeks. 
The quantitative data analysis was conducted by using the Wilcoxon matchedpairs, signed ranks test. The survey returned results that had 13 out of the 29 survey questions with significant results at the .05 level. Survey questions in all constructs had significant results were, but there were more survey questions that had significant results in the constructs of Problem Solving and Resilience than the other constructs.

Table 4. Test Statistics A

\begin{tabular}{|l|r|r|}
\hline & \multicolumn{1}{|c|}{ Z } & $\begin{array}{r}\text { Asymp. Sig. } \\
\text { (2-tailed) }\end{array}$ \\
\hline Q1 Start - Q1 End & $-1.048^{\mathrm{b}}$ & .295 \\
Q2 Start - Q2 End & $-1.422^{\mathrm{c}}$ & .155 \\
Q3 Start - Q3 End & $-.303^{\mathrm{b}}$ & .762 \\
Q4 Start - Q4 End & $-1.408^{\mathrm{b}}$ & .159 \\
Q5 Start - Q5 End & $-2.209^{\mathrm{b}}$ & $.027^{*}$ \\
Q6 Start - Q6 End & $-2.373^{\mathrm{b}}$ & $.018^{*}$ \\
Q7 Start - Q7 End & $-1.710^{\mathrm{c}}$ & .087 \\
Q8 Start - Q8 End & $-2.066^{\mathrm{b}}$ & $.039^{*}$ \\
Q9 Start - Q9 End & $-2.157^{\mathrm{b}}$ & $.031^{*}$ \\
Q10 Start - Q10 End & $-2.209^{\mathrm{b}}$ & $.027^{*}$ \\
Q11 Start - Q11 End & $-.577^{\mathrm{c}}$ & .564 \\
Q12 Start - Q12 End & $-1.725^{\mathrm{b}}$ & .084 \\
Q13 Start - Q13 End & $-1.100^{\mathrm{b}}$ & .271 \\
Q14 Start - Q14 End & $-1.518^{\mathrm{b}}$ & .129 \\
Q15 Start - Q15 End & $-1.768^{\mathrm{c}}$ & .077 \\
Q16 Start - Q16 End & $-1.852^{\mathrm{c}}$ & .064 \\
Q17 Start - Q17 End & $-.541^{\mathrm{b}}$ & .589 \\
Q18 Start - Q18 End & $-1.983^{\mathrm{b}}$ & $.047^{\mathrm{b}}$ \\
Q19 Start - Q19 End & $-2.154^{\mathrm{b}}$ & $.031^{*}$ \\
Q20 Start - Q20 End & $-2.359^{\mathrm{b}}$ & $.018^{*}$ \\
Q21 Start - Q21 End & $-2.530^{\mathrm{b}}$ & $.011^{*}$ \\
Q22 Start - Q22 End & $-2.111^{\mathrm{b}}$ & $.035^{*}$ \\
Q23 Start - Q23 End & $-1.903^{\mathrm{b}}$ & .057 \\
Q24 Start - Q24 End & $-1.540^{\mathrm{c}}$ & .124 \\
Q25 Start - Q25 End & $-2.565^{\mathrm{b}}$ & $.010^{* *}$ \\
Q26 Start - Q26 End & $-1.265^{\mathrm{b}}$ & .206 \\
Q27 Start - Q27 End & $-2.667^{\mathrm{b}}$ & $.008^{* *}$ \\
Q28 Start - Q28 End & $-.541^{\mathrm{b}}$ & .589 \\
Q29 Start - Q29 End & $-2.333^{\mathrm{b}}$ & $.020^{\mathrm{b}}$ \\
\hline
\end{tabular}


Table 5.

Ranks

\begin{tabular}{|c|c|c|c|c|}
\hline & & $\mathrm{N}$ & $\begin{array}{l}\text { Mean } \\
\text { Rank }\end{array}$ & $\begin{array}{l}\text { Sum of } \\
\text { Ranks }\end{array}$ \\
\hline \multirow{4}{*}{$\begin{array}{l}\text { Q5 End - } \\
\text { Q5 Start }\end{array}$} & Negative Ranks & 1 & 2.50 & 2.50 \\
\hline & Positive Ranks & 7 & 4.79 & 33.50 \\
\hline & Ties & 12 & & \\
\hline & Total & 20 & & \\
\hline \multirow{4}{*}{$\begin{array}{l}\text { Q6 End - } \\
\text { Q6 Start }\end{array}$} & Negative Ranks & 1 & 3.00 & 3.00 \\
\hline & Positive Ranks & 8 & 5.25 & 42.00 \\
\hline & Ties & 11 & & \\
\hline & Total & 20 & & \\
\hline \multirow{4}{*}{$\begin{array}{l}\text { Q8 End - } \\
\text { Q8 Start }\end{array}$} & Negative Ranks & 2 & 4.00 & 8.00 \\
\hline & Positive Ranks & 8 & 5.88 & 47.00 \\
\hline & Ties & 10 & & \\
\hline & Total & 20 & & \\
\hline \multirow{4}{*}{$\begin{array}{l}\text { Q9 End - } \\
\text { Q9 Start }\end{array}$} & Negative Ranks & 1 & 3.00 & 3.00 \\
\hline & Positive Ranks & 7 & 4.71 & 33.00 \\
\hline & Ties & 12 & & \\
\hline & Total & 20 & & \\
\hline \multirow{4}{*}{$\begin{array}{l}\text { Q10 End - } \\
\text { Q10 Start }\end{array}$} & Negative Ranks & 1 & 2.50 & 2.50 \\
\hline & Positive Ranks & 7 & 4.79 & 33.50 \\
\hline & Ties & 12 & & \\
\hline & Total & 20 & & \\
\hline \multirow{4}{*}{$\begin{array}{l}\text { Q18 End - } \\
\text { Q18 Start }\end{array}$} & Negative Ranks & 1 & 2.50 & 2.50 \\
\hline & Positive Ranks & 6 & 4.25 & 25.50 \\
\hline & Ties & 13 & & \\
\hline & Total & 20 & & \\
\hline \multirow{4}{*}{$\begin{array}{l}\text { Q20 End - } \\
\text { Q20 Start }\end{array}$} & Negative Ranks & 3 & 5.50 & 16.50 \\
\hline & Positive Ranks & 11 & 8.05 & 88.50 \\
\hline & Ties & 6 & & \\
\hline & Total & 20 & & \\
\hline \multirow{4}{*}{$\begin{array}{l}\text { Q21 End - } \\
\text { Q21 Start }\end{array}$} & Negative Ranks & 0 & .00 & .00 \\
\hline & Positive Ranks & 7 & 4.00 & 28.00 \\
\hline & Ties & 13 & & \\
\hline & Total & 20 & & \\
\hline \multirow{4}{*}{$\begin{array}{l}\text { Q19 End - } \\
\text { Q19 Start }\end{array}$} & Negative Ranks & 1 & 3.00 & 3.00 \\
\hline & Positive Ranks & 7 & 4.71 & 33.00 \\
\hline & Ties & 12 & & \\
\hline & Total & 20 & & \\
\hline \multirow{4}{*}{$\begin{array}{l}\text { Q22 End - } \\
\text { Q22 Start }\end{array}$} & Negative Ranks & 2 & 6.00 & 12.00 \\
\hline & Positive Ranks & 9 & 6.00 & 54.00 \\
\hline & Ties & 9 & & \\
\hline & Total & 20 & & \\
\hline \multirow{4}{*}{$\begin{array}{l}\text { Q25 End - } \\
\text { Q25 Start }\end{array}$} & Negative Ranks & 1 & 3.00 & 3.00 \\
\hline & Positive Ranks & 9 & 5.78 & 52.00 \\
\hline & Ties & 10 & & \\
\hline & Total & 20 & & \\
\hline \multirow{2}{*}{$\begin{array}{l}\text { Q27 End - } \\
\text { Q27 Start }\end{array}$} & Negative Ranks & 1 & 4.00 & 4.00 \\
\hline & Positive Ranks & 10 & 6.20 & 62.00 \\
\hline
\end{tabular}




\begin{tabular}{|ll|r|r|r|} 
& Ties & 9 & & \\
Total & 20 & & \\
\hline Q29 End - & Negative Ranks & 0 & .00 & .00 \\
Q29 Start & Positive Ranks & 6 & 3.50 & 21.00 \\
& Ties & 14 & & \\
& Total & 20 & & \\
\hline
\end{tabular}

Table 6. Test Statistics B

\begin{tabular}{|l|l|r|}
\hline & Z & $\begin{array}{c}\text { Asymp. Sig. } \\
\text { (2-tailed) }\end{array}$ \\
\hline Q5 End - Q5 Start & $-2.209^{\mathrm{b}}$ & .027 \\
Q6 End - Q6 Start & $-2.373^{\mathrm{b}}$ & .018 \\
Q8 End - Q8 Start & $-2.066^{\mathrm{b}}$ & .039 \\
Q9 End - Q9 Start & $-2.157^{\mathrm{b}}$ & .031 \\
Q10 End - Q10 Start & $-2.209^{\mathrm{b}}$ & .027 \\
Q18 End - Q18 Start & $-1.983^{\mathrm{b}}$ & .047 \\
Q20 End - Q20 Start & $-2.359^{\mathrm{b}}$ & .018 \\
Q21 End - Q21 Start & $-2.530^{\mathrm{b}}$ & .011 \\
Q19 End - Q19 Start & $-2.154^{\mathrm{b}}$ & .031 \\
Q22 End - Q22 Start & $-2.111^{\mathrm{b}}$ & .035 \\
Q25 End - Q25 Start & $-2.565^{\mathrm{b}}$ & .010 \\
Q27 End - Q27 Start & $-2.667^{\mathrm{b}}$ & .008 \\
Q29 End - Q29 Start & $-2.333^{\mathrm{b}}$ & .020 \\
\hline
\end{tabular}

a. Wilcoxon Signed Ranks Test

b. Based on negative ranks.

\section{Motivation}

Bandura (1988) contends the role of self-efficacy beliefs in human functioning are that a person's level of motivation, emotional states, and actions are based on what a person believes than on what is objectively true. Therefore, a person's actions are controlled more by their beliefs in their abilities than by what they are capable of accomplishing. For self-efficacy, perceptions are the main contributors to what individuals do with the knowledge and skills they possess. The first construct of selfefficacy, motivation, was assessed using classroom observations by the researcher in conjunction with personal interviews and by the following retrospective survey questions: 
Table 7. Motivation

\begin{tabular}{|c|c|c|c|c|c|}
\hline Motivation & $\begin{array}{l}\text { SQ1. I } \\
\text { try my } \\
\text { best } \\
\text { even } \\
\text { when it } \\
\text { is a } \\
\text { difficult } \\
\text { task. }\end{array}$ & $\begin{array}{l}\text { SQ7. } \\
\text { When I } \\
\text { experience } \\
\text { failure, I } \\
\text { stop } \\
\text { trying. } \\
* * *\end{array}$ & $\begin{array}{l}\text { SQ13. } \\
\text { I keep } \\
\text { trying } \\
\text { when } \\
\text { things } \\
\text { get } \\
\text { hard. }\end{array}$ & $\begin{array}{l}\text { SQ15. } \\
\text { I give } \\
\text { up } \\
\text { when } \\
\text { things } \\
\text { get } \\
\text { hard. } \\
* * *\end{array}$ & $\begin{array}{l}\text { SQ27. I recover } \\
\text { quickly from } \\
\text { setbacks and } \\
\text { disappointments. }\end{array}$ \\
\hline $1^{*}$ & $4-3$ & $2-2$ & $4-4$ & $2-2$ & $3-3$ \\
\hline 2 & $4-3$ & $2-3$ & $3-4$ & $2-2$ & $2-4$ \\
\hline 3 & $3-4$ & $2-2$ & $4-4$ & $2-2$ & $3-4$ \\
\hline 4 & $1-4$ & 4-2 & $3-3$ & 4-3 & $2-4$ \\
\hline 5 & $3-4$ & $3-3$ & $3-3$ & $2-2$ & $4-4$ \\
\hline 6 & $3-5$ & $5-3$ & $5-5$ & $5-2$ & $3-4$ \\
\hline 7 & 4-5 & $1-1$ & $5-5$ & $1-1$ & 4-5 \\
\hline 8 & $5-4$ & $3-3$ & $2-3$ & $4-3$ & $3-4$ \\
\hline 9 & $2-5$ & $4-2$ & $2-4$ & $4-3$ & $2-4$ \\
\hline 10 & $3-3$ & $3-3$ & $3-3$ & $3-3$ & $3-3$ \\
\hline 11 & $3-4$ & 4-2 & $2-4$ & 4-2 & $2-4$ \\
\hline 12 & $3-3$ & $3-4$ & $3-4$ & 4-2 & $3-4$ \\
\hline 13 & $5-4$ & $2-2$ & $3-3$ & $2-2$ & $4-4$ \\
\hline 14 & $3-4$ & $3-3$ & $3-3$ & $3-3$ & $1-1$ \\
\hline 15 & $4-3$ & 4-3 & $4-3$ & 4-3 & $3-4$ \\
\hline 16 & $4-3$ & $3-3$ & $4-3$ & $2-3$ & $3-2$ \\
\hline 17 & $5-5$ & $1-1$ & $5-5$ & $1-1$ & $5-5$ \\
\hline 18 & $5-3$ & $2-2$ & $4-3$ & $2-4$ & $3-3$ \\
\hline 19 & $4-4$ & $1-1$ & $4-4$ & $1-1$ & $4-4$ \\
\hline 20 & $1-5$ & $5-1$ & $1-1$ & $3-1$ & $1-1$ \\
\hline Averages** & $\begin{array}{c}3.37- \\
3.84\end{array}$ & $2.8-2.35$ & $\begin{array}{c}3.05- \\
3.29\end{array}$ & $\begin{array}{c}2.75- \\
2.25\end{array}$ & $2.78-3.47$ \\
\hline Change & +0.47 & -0.45 & +0.24 & -0.5 & +0.69 \\
\hline \multicolumn{6}{|c|}{$\begin{array}{l}\text { *The scores are the retrospective pre- and post-scores for each item and } \\
\text { each participant. } \\
* * \text { Numeric average of the pre- and post-scores. } \\
* * * \text { Answers negatively coded. }\end{array}$} \\
\hline
\end{tabular}

For the construct of Motivation, the students were probed for changes in using the above question. Scale growth ranged from $0.23-.68$ on a Likert scale for these survey questions. Responses that had growth ceiling Likert scores were not used in the average 
growth calculations. Of these five questions four returned significant results. Q5 "Learning to build boats is interesting to me.” returned significant results, a Wilcoxon matched-pairs, signed ranks test showed that the self-efficacy change from the pre (Md = 3.15, Range $=3$, Min, $\max =1,4)$ and post $(\operatorname{Md}=3.70$, Range $=3$, Min, $\max =2,5)$ was significant beyond the .05 level: Asymptotic $p=.027$ (two-tailed). The sums of ranks were 2.5 and 33.5 for the negative and positive ranks, respectively, therefore $\mathrm{W}=2.5$. The matched-pairs rank biserial correlation is .15, which is a 'small' effect.

Q9 “When I work hard on something it shows in the results.” returned significant results, a Wilcoxon matched-pairs, signed ranks test showed that the self-efficacy change from the pre $(\mathrm{Md}=3.7$, Range $=4$, Min, $\max =1,5)$ and post $(\mathrm{Md}=4.2$, Range $=2$, Min, $\max =3,5$ ) was significant beyond the .05 level: Asymptotic $p=.031$ (two-tailed). The sums of ranks were 3.0 and 33.0 for the negative and positive ranks, respectively, therefore $\mathrm{W}=3$. The matched-pairs rank biserial correlation is .14, which is a 'small' effect.

Q18 “I care about my project.” returned significant results, a Wilcoxon matchedpairs, signed ranks test showed that the self-efficacy change from the pre $(\mathrm{Md}=3.5$, Range $=4$, Min, $\max =1,5)$ and post $(\operatorname{Md}=3.9$, Range $=2$, Min, $\max =3,5)$ was significant beyond the .05 level: Asymptotic $\mathrm{p}=.047$ (two-tailed). The sums of ranks were 2.5 and 25.5 for the negative and positive ranks, respectively, therefore $\mathrm{W}=2.5$. The matched-pairs rank biserial correlation is .11, which is a 'small' effect.

Q20 “I can make valuable contributions to a project.” returned significant results, a Wilcoxon matched-pairs, signed ranks test showed that the self-efficacy change from the pre $(\mathrm{Md}=3.05$, Range $=4$, Min, $\max =1,5)$ and post $(\mathrm{Md}=3.75$, Range $=2$, Min, 
$\max =3,5$ ) was significant beyond the .05 level: Asymptotic $p=.018$ (two-tailed). The sums of ranks were 16.5 and 88.5 for the negative and positive ranks, respectively, therefore $\mathrm{W}=16.5$. The matched-pairs rank biserial correlation is .34, which is a 'moderate' effect. The results seem to indicate that after participation in the program the students show an increased level of motivation after participation in this program. The Wilcoxon signed rank test shows that the observed difference between both measurements is significant. Thus, we can reject the null hypothesis that both samples are from the same population, the results suggest that participation in the program caused a small to moderate increase in students self-perceived level of motivation.

Research shows that self-efficacy is indicative of cognitive skill learning and attendance (Bandura, 1988). The program found that student attendance while in the program was comparable between male and female participants with overall attendance averages of $86 \%$ for males and $85 \%$ for females. This contrasts with the overall combined student attendance average $88 \%$ at the same high school. The average attendance rate of the students gradually increased with participation in more wheels of the program. Attendance averages went from an average attendance low of $84 \%$ in the 31-day wheel, to an average attendance high of $96 \%$ for the students that participated in the full 126-day (four wheels) program. 
Table 8.

\section{Attendance}

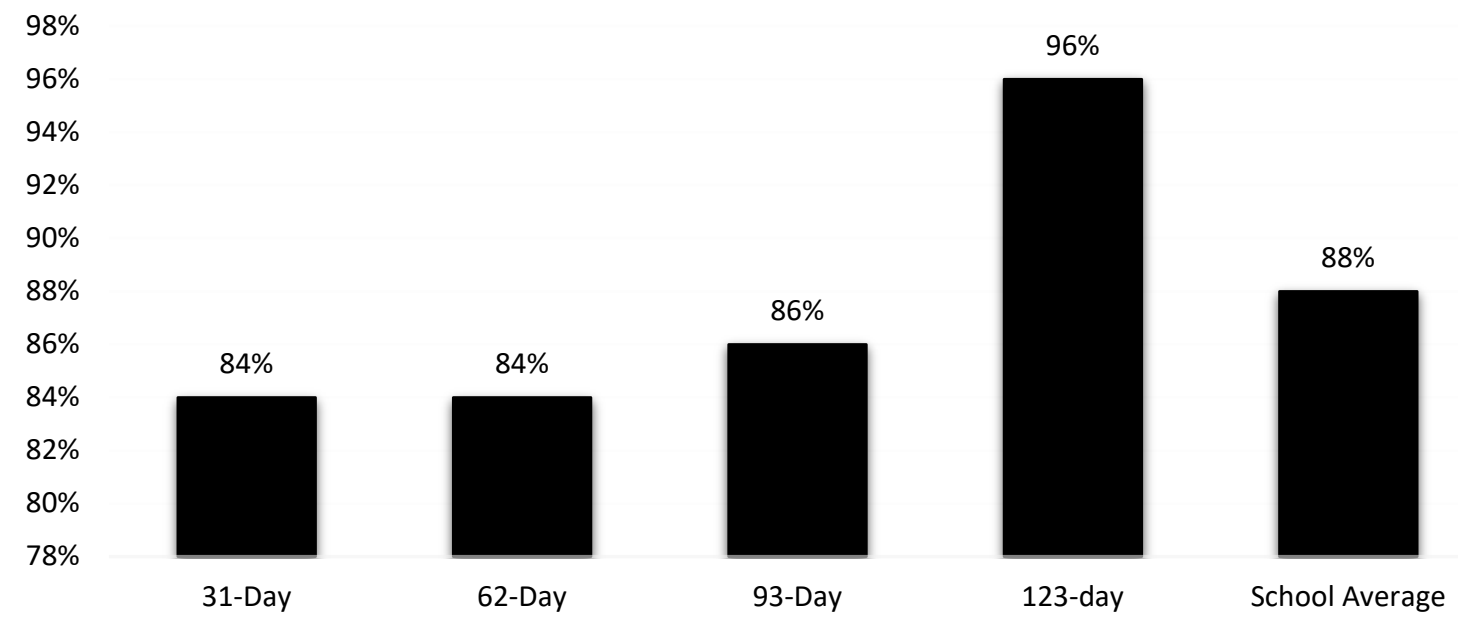

Of the six females that participated four of them had attendance averages over $90 \%$ and the remaining two averaged less than $70 \%$ attendance in the program. The male attendance average was consistent throughout the program regardless of the number of wheels enrolled except for the one male that participated in the full 126-day (four wheels) program, who had a 96\% attendance rate. The two students, one female and one male, participated in the full 126-day treatment had an attendance average of 95.5\%. Goal setting and self-monitoring plays an important part in cultivating self-motivation and selfefficacy (Bandura, 1997).

Though attendance levels demonstrated a gradual increase with longer exposure to the program, no direct correlation was found between student attendance and student GPA in either male students or female students that participated in the program.

During student interviews, Students were asked why they had chosen to take part in the program. Understanding what was the initial motivation for the students attending 
gave the researcher a baseline about the students' motivational reasons and gave insight as to whether there were any positive or negative changes in the motivation of the students. When asked "Why did you choose to be a part of this program?”, 55\% of the participants stated that they wanted math credit, whereas only $15 \%$ joined because they thought that it would be fun or exciting. Furthermore, when asked about what the students liked about the program, no discernable patterns in what they liked about the program by gender or participation length were found. Finally, there did not seem to be a pattern amongst student interview responses to the elements of the program that they found interesting.

Course Skills

The course skills that the Wind and Oar Boat school have integrated into their curriculum encompassed the mathematics and geometry skills utilized in the boat building process. Many of these concepts are as simple as the addition of fractions used in measurements and are as advanced as the Pythagorean theorem that is used to build the boat and other pieces related to the build. The students apply what they learn in a handson, engineering math lesson that requires them to design different facets of the boat. Students are then able to gain a better grasp of how to take accurate measurements and how to read a standard ruler. The second construct of self-efficacy, Course Skills, was assessed using classroom observations by the researcher in conjunction with personal interviews and by the following questions from the retrospective survey: 
Table 9. Course Skills

\begin{tabular}{|c|c|c|c|c|c|}
\hline $\begin{array}{l}\text { Course } \\
\text { Skills }\end{array}$ & $\begin{array}{l}\text { SQ2. *** } \\
\text { Things I } \\
\text { learn in } \\
\text { this class } \\
\text { are not } \\
\text { useful } \\
\text { outside of } \\
\text { school. }\end{array}$ & $\begin{array}{l}\text { SQ10. } \\
\text { Using } \\
\text { math is } \\
\text { an } \\
\text { important } \\
\text { skill in } \\
\text { life. }\end{array}$ & $\begin{array}{l}\text { SQ14. I } \\
\text { can use } \\
\text { math } \\
\text { outside of } \\
\text { the } \\
\text { classroom. }\end{array}$ & $\begin{array}{l}\text { SQ23. } \\
\text { Learning } \\
\text { to do } \\
\text { math is } \\
\text { important } \\
\text { to me. }\end{array}$ & $\begin{array}{l}\text { SQ25. I } \\
\text { can use } \\
\text { math on } \\
\text { a } \\
\text { project. }\end{array}$ \\
\hline $1^{*}$ & $3-3$ & $4-4$ & $4-4$ & $4-4$ & $4-4$ \\
\hline 2 & $3-4$ & $2-3$ & $4-4$ & $1-2$ & $4-4$ \\
\hline 3 & $1-5$ & $4-4$ & $5-5$ & $2-4$ & $4-4$ \\
\hline 4 & $5-2$ & $4-4$ & $3-3$ & $4-4$ & $2-4$ \\
\hline 5 & $1-1$ & $3-3$ & $4-4$ & $4-4$ & $4-4$ \\
\hline 6 & $3-2$ & $2-4$ & $4-4$ & $3-5$ & $2-4$ \\
\hline 7 & 4-2 & $5-5$ & $4-4$ & $5-5$ & $4-4$ \\
\hline 8 & $3-1$ & $3-4$ & $2-2$ & $3-4$ & $2-3$ \\
\hline 9 & $4-2$ & $2-4$ & $2-4$ & $2-4$ & $2-4$ \\
\hline 10 & $2-2$ & $3-3$ & $4-4$ & $2-2$ & $4-4$ \\
\hline 11 & $4-3$ & $1-3$ & $3-4$ & $2-2$ & $2-4$ \\
\hline 12 & $3-2$ & $3-4$ & $3-4$ & $4-4$ & $3-4$ \\
\hline 13 & $3-3$ & $4-4$ & $4-4$ & $3-4$ & $3-3$ \\
\hline 14 & 3-1 & $5-5$ & $5-5$ & $4-4$ & $5-5$ \\
\hline 15 & $2-2$ & $4-3$ & $4-4$ & $3-4$ & $3-4$ \\
\hline 16 & $2-2$ & $3-3$ & $4-3$ & $4-3$ & $4-3$ \\
\hline 17 & $1-1$ & $5-5$ & $4-4$ & $4-4$ & $3-3$ \\
\hline 18 & $5-4$ & $3-3$ & $3-3$ & $2-2$ & $2-2$ \\
\hline 19 & $2-1$ & $5-5$ & $4-4$ & $3-3$ & $3-4$ \\
\hline 20 & $2-4$ & $1-4$ & $3-5$ & $2-1$ & $1-3$ \\
\hline Averages** & $2.8-2.35$ & 3.3-3.85 & $3.65-3.9$ & $3.05-3.45$ & $3.05-3.7$ \\
\hline Change & -0.45 & +0.55 & +0.25 & +0.40 & +0.65 \\
\hline \multicolumn{6}{|c|}{$\begin{array}{l}\text { *The scores are the retrospective pre- and post-scores for each item and } \\
\text { each participant. } \\
* * \text { Numeric average of the pre- and post-scores. } \\
* * * \text { Answers negatively coded. }\end{array}$} \\
\hline
\end{tabular}

For the construct, Course Skills, the students were probed for changes in using the above question. Scale growth ranged from $0.27-.65$ on a Likert scale for these survey questions. Responses that had growth ceiling Likert scores were not used in the average growth calculations. Of these five questions Q10 "Using math is an important skill in life” returned significant results, a Wilcoxon matched-pairs, signed ranks test showed that 
the self-efficacy change from the pre $(\mathrm{Md}=3.3$, Range $=4$, Min, $\max =1,5)$ and post $(\mathrm{Md}=3.85$, Range $=2$, Min, $\max =3,5)$ was significant beyond the .05 level: Asymptotic $\mathrm{p}=.027$ (two-tailed). The sums of ranks were 2.5 and 33.5 for the negative and positive ranks, respectively, therefore $\mathrm{W}=2.5$. The matched-pairs rank biserial correlation is .15, which is a 'small' effect.

Additionally, Q25 “I can use math on a project” returned significant results, a Wilcoxon matched-pairs, signed ranks test showed that the self-efficacy change from the pre $(\mathrm{Md}=3.05$, Range $=4$, Min, $\max =1,5)$ and post $(\mathrm{Md}=3.7$, Range $=3$, Min, $\max$ $=2,5$ ) was significant beyond the .05 level: Asymptotic $p=.010$ (two-tailed). The sums of ranks were 3 and 52 for the negative and positive ranks, respectively, therefore $\mathrm{W}=3$. The matched-pairs rank biserial correlation is .234, which is a 'small' effect. The Wilcoxon signed rank test shows that the observed difference between both measurements is significant. Therefore, we can reject the null hypothesis that both samples are from the same population, the results suggest that participation in the program caused a small increase in students' abilities to use course skills outside of the classroom.

When the students were asked in their interviews, $100 \%$ of the students that participated in the program stated that they now felt very comfortable working with and around tools after participating in this program. Furthermore, all students that participated in the program received math credit for their participation in the course. In informal interviews with students that had left the program after one or two wheels stated that they 
could use the simple math skills they had learned in the program in another math class they were taking.

\section{Resilience}

The researcher defined resilience, as the set of attributes that provides students with the fortitude to confront the obstacles they are bound to face in school and life. The third construct of self-efficacy, Resilience, was assessed using classroom observations by the researcher in conjunction with personal interviews and by the following questions from the retrospective survey:

Table 10. Resilience

\begin{tabular}{|c|c|c|c|c|c|}
\hline Resilience & $\begin{array}{l}\text { SQ5. } \\
\text { Learning to } \\
\text { build boats } \\
\text { is } \\
\text { interesting } \\
\text { to me. }\end{array}$ & $\begin{array}{l}\text { SQ9. } \\
\text { When I } \\
\text { work hard } \\
\text { on } \\
\text { something } \\
\text { it shows in } \\
\text { the results. }\end{array}$ & $\begin{array}{l}\text { SQ18. I } \\
\text { care } \\
\text { about } \\
\text { my } \\
\text { project. }\end{array}$ & $\begin{array}{l}\text { SQ20. I can } \\
\text { make } \\
\text { valuable } \\
\text { contributions } \\
\text { to a project. }\end{array}$ & $\begin{array}{l}\text { SQ26. I am } \\
\text { able to try } \\
\text { harder when } \\
\text { the teacher } \\
\text { gives me } \\
\text { encouragement. }\end{array}$ \\
\hline $1 *$ & $3-3$ & $5-5$ & $3-3$ & $3-3$ & $3-3$ \\
\hline 2 & $3-4$ & $3-4$ & $4-4$ & $2-4$ & 4-5 \\
\hline 3 & $4-4$ & $4-4$ & $4-4$ & $4-4$ & $5-5$ \\
\hline 4 & $2-4$ & 4-5 & $1-4$ & $2-4$ & $2-4$ \\
\hline 5 & $4-4$ & $4-4$ & $4-4$ & $4-4$ & $3-5$ \\
\hline 6 & 4-5 & 4-5 & $5-5$ & $3-4$ & $5-5$ \\
\hline 7 & $4-4$ & $5-5$ & $5-5$ & $4-5$ & $3-3$ \\
\hline 8 & $4-4$ & $3-4$ & $3-3$ & $2-3$ & $2-2$ \\
\hline 9 & $2-5$ & $2-4$ & $3-3$ & $2-3$ & $4-4$ \\
\hline 10 & $4-4$ & $4-4$ & $4-4$ & $3-3$ & $3-3$ \\
\hline 11 & $2-4$ & $2-4$ & $2-4$ & $1-4$ & $3-4$ \\
\hline 12 & $3-3$ & $3-3$ & $3-4$ & $3-4$ & $3-4$ \\
\hline 13 & $3-3$ & $5-5$ & $3-4$ & $5-4$ & $5-4$ \\
\hline 14 & $3-3$ & $3-3$ & $3-4$ & $3-4$ & $3-3$ \\
\hline 15 & $3-3$ & $4-4$ & $4-4$ & $3-4$ & $4-4$ \\
\hline 16 & $4-4$ & $4-3$ & $4-4$ & $4-3$ & $4-3$ \\
\hline 17 & $3-4$ & $5-5$ & $5-5$ & $4-4$ & $4-4$ \\
\hline
\end{tabular}




\begin{tabular}{|c|c|c|c|c|c|}
\hline 18 & $3-2$ & $4-4$ & $4-4$ & $4-3$ & $2-2$ \\
\hline 19 & $4-4$ & $5-5$ & $4-3$ & $4-4$ & $3-3$ \\
\hline 20 & $1-3$ & $1-4$ & $2-4$ & $1-4$ & $4-5$ \\
\hline Averages** & $3.15-3.7$ & $3.47-4.06$ & $\begin{array}{c}3.24- \\
3.76 \\
\end{array}$ & $3.05-3.75$ & $3.28-3.50$ \\
\hline Change & +0.55 & +0.59 & +0.52 & +0.70 & +0.22 \\
\hline \multicolumn{6}{|c|}{$\begin{array}{l}\text { *The scores are the retrospective pre- and post-scores for each item and each } \\
\text { participant. } \\
* * \text { Numeric average of the pre- and post-scores. } \\
* * * \text { Answers negatively coded. }\end{array}$} \\
\hline
\end{tabular}

For the construct of Resilience, the students were probed for changes in using the above question. Scale growth ranged from 0.2 - .7 on a Likert scale for these survey questions. Responses that had growth ceiling Likert scores were not used in the average growth calculations. Of these five questions, only Q27 “I recover quickly from setbacks and disappointments” returned significant results, a Wilcoxon matched-pairs, signed ranks test showed that the self-efficacy change from the pre $(M d=2.9$, Range $=4$, Min, $\max =1,5)$ to post $(\mathrm{Md}=3.55$, Range $=4$, Min, $\max =1,5)$ was significant beyond the .05 level: Asymptotic p=.008 (two-tailed). The sums of ranks were 4 and 62 for the negative and positive ranks, respectively, therefore $W=4$. The matched-pairs rank biserial correlation is .28, which is a 'small' effect. The results seem to indicate that after participation in the program the students show a slightly increased sense of resilience. The Wilcoxon signed rank test shows that the observed difference between both measurements is significant. Thus, we can reject the null hypothesis that both samples are from the same population.

During student interviews they were asked "What aspect of this program influenced you to stay in or leave the program? Fifty percent of the female students stated that they wanted to continue in the program because they wanted to finish the project 
whereas only $5 \%$ of the male students stated that they wanted to continue in the program because they wanted to finish the project. Additionally, $20 \%$ of the male students stated in their interviews, that they were motivated to stay in the program because of their interactions with the instructors.

Furthermore, when asked in student interviews, if the participation in this program changed their perception of their level of achievement in school? Fifty percent of the female students stated that participation in this program changed their perception of their achievement in school by teaching them to never give up when they encounter a difficult situation whereas only $25 \%$ of the male students gave a similar response.

\section{Teamwork}

When the term "project-based learning" (PBL) is applied to an activity, students are guided in long-term challenges that involve real-life problems. Students see the complexity of a job or business with eyes that understand the multiple processes that go into the creation of the project. Thereby helping them prepare more efficiently for the real challenges ahead. This construct of teamwork sought to capture the students' feelings of how the PBL activity allowed them to learn in an environment that fosters communication and collaboration in a manner that increased trust in others. The fourth construct of self-efficacy, Teamwork, Collaboration and Communication Skills, was assessed using observations by the researcher in conjunction with personal interviews and by the following questions from the retrospective survey: 
Table 11. Teamwork

\begin{tabular}{|c|c|c|c|c|}
\hline Teamwork & $\begin{array}{l}\text { SQ4. I value } \\
\text { working with } \\
\text { other students. }\end{array}$ & $\begin{array}{l}\text { SQ11. *** I like } \\
\text { to solve problems } \\
\text { on my own } \\
\text { without help. }\end{array}$ & $\begin{array}{l}\text { SQ17. I can } \\
\text { learn from } \\
\text { my } \\
\text { classmates. }\end{array}$ & $\begin{array}{l}\text { SQ29. I help } \\
\text { my } \\
\text { classmates } \\
\text { with } \\
\text { projects. }\end{array}$ \\
\hline $1 *$ & $2-2$ & $4-4$ & $3-3$ & $3-3$ \\
\hline 2 & 4-5 & $5-5$ & $3-5$ & 4-5 \\
\hline 3 & $2-3$ & $4-4$ & $4-4$ & $3-3$ \\
\hline 4 & $3-4$ & $2-3$ & 4-5 & $4-4$ \\
\hline 5 & 4-4 & 3-3 & 4-4 & 4-4 \\
\hline 6 & $3-5$ & $3-4$ & $4-4$ & $5-5$ \\
\hline 7 & $5-5$ & $5-5$ & $4-4$ & $5-5$ \\
\hline 8 & 3-3 & 3-3 & $2-2$ & 3-3 \\
\hline 9 & $4-4$ & $2-2$ & $4-4$ & $3-4$ \\
\hline 10 & $3-3$ & $2-2$ & $4-4$ & $4-4$ \\
\hline 11 & 4-2 & 5-3 & 3-4 & $2-4$ \\
\hline 12 & $3-3$ & $2-3$ & $3-3$ & $3-4$ \\
\hline 13 & $3-4$ & $2-3$ & $4-4$ & $5-5$ \\
\hline 14 & $3-4$ & $3-2$ & $3-4$ & 4-5 \\
\hline 15 & $4-4$ & $4-3$ & $4-4$ & $3-3$ \\
\hline 16 & $3-3$ & $3-2$ & $3-2$ & $3-3$ \\
\hline 17 & 4-4 & 4-4 & 4-4 & 3-3 \\
\hline 18 & $4-4$ & $2-2$ & $4-4$ & $4-4$ \\
\hline 19 & 4-3 & 4-4 & 3-3 & 3-3 \\
\hline 20 & 1-4 & $3-2$ & 3-1 & 3-4 \\
\hline Averages** & $3.34-3.58$ & $3.16-3.05$ & $3.5-3.60$ & $3.29-3.71$ \\
\hline Change & 0.24 & -0.11 & 0.1 & 0.42 \\
\hline \multicolumn{5}{|c|}{$\begin{array}{l}\text { *The scores are the retrospective pre- and post-scores for each item and each } \\
\text { participant. } \\
* * \text { Numeric average of the pre- and post-scores. } \\
* * * \text { Answers negatively coded. }\end{array}$} \\
\hline
\end{tabular}

For the construct of Teamwork, the students were probed for changes in using the above question. Scale growth ranged from $0.1-.36$ on a Likert scale for these survey questions. Responses that had growth ceiling Likert scores were not used in the average growth calculations. Of these four questions, only Q29 “I help my classmates with projects” returned significant results, a Wilcoxon matched-pairs, signed ranks test 
showed that the self-efficacy change from the pre $(\mathrm{Md}=3.55$, Range $=3$, Min, $\max =2$, 5) and post $(\mathrm{Md}=3.9$, Range $=2$, Min, $\max =3,5)$ was significant beyond the .05 level: Asymptotic $\mathrm{p}=.047$ (two-tailed). The sums of ranks were 0.0 and 21 for the negative and positive ranks, respectively, therefore $\mathrm{W}=0$. The matched-pairs rank biserial correlation is .1, which is a 'small' effect. The results seem to indicate that after participation in the program the students show a slightly increased level of teamwork, or ability to collaborate, after participation in this program. The Wilcoxon signed rank test shows that the observed difference between both measurements is significant. Accordingly, we can reject the null hypothesis that both samples are from the same population, and we might assume that participation in the program caused a small increase in students selfperceived level of teamwork or ability to collaborate.

In student interviews, they were asked "How have your communication skills changed during your participation in this program?” and 95\% of the students felt that their communication skills had improved after they had participated in this program. Only one student stated that they did not see an improvement in their communication skills after participating in this program. When asked "How have your collaboration skills changed during your participation in this program?” $85 \%$ of the students stated that their collaboration skills had improved. Some of the students even stated that they liked working in teams better now, contrasting to how they felt before they participated in the program. 


\section{Confidence}

Student confidence is an important aspect in educational success. With an increasing number of students being harassed or bullied, student confidence in school and at home can suffer, which usually results in the grades of the student suffering as a byproduct of the harassment or bullying. Increasing student confidence is one of the most important steps educators, and parents can take to ensure an atmosphere for learning. When a student loses student self-esteem, they may lose motivation in learning. The fifth construct of self-efficacy, Confidence, was assessed using classroom observations by the researcher in conjunction with personal interviews and by the following questions from the retrospective survey:

Table 12. Confidence

\begin{tabular}{|c|c|c|c|c|c|}
\hline Confidence & $\begin{array}{l}\text { SQ3. I cannot } \\
\text { follow complex } \\
\text { instructions } \\
\text { unless someone } \\
\text { shows me how } \\
\text { to do it. }\end{array}$ & $\begin{array}{l}\text { SQ8. I can plan } \\
\text { out projects } \\
\text { from start to } \\
\text { finish. }\end{array}$ & $\begin{array}{l}\text { SQ16. I } \\
\text { believe that } \\
\text { difficult tasks } \\
\text { are beyond } \\
\text { my } \\
\text { capabilities. } \\
* * *\end{array}$ & $\begin{array}{l}\text { SQ21. I can } \\
\text { perform a new } \\
\text { task when } \\
\text { someone } \\
\text { shows me how. }\end{array}$ & $\begin{array}{l}\text { SQ24. I } \\
\text { avoid } \\
\text { challenging } \\
\text { tasks. *** }\end{array}$ \\
\hline $1 *$ & $2-2$ & $3-3$ & $2-2$ & $4-4$ & $3-3$ \\
\hline 2 & $4-3$ & $2-4$ & $2-2$ & $3-4$ & $2-1$ \\
\hline 3 & $3-5$ & $2-3$ & $2-2$ & $3-4$ & 4-2 \\
\hline 4 & $4-4$ & $2-3$ & $3-4$ & 4-5 & $3-3$ \\
\hline 5 & $3-3$ & $4-4$ & $2-2$ & $3-3$ & $3-3$ \\
\hline 6 & $3-3$ & $3-5$ & $3-3$ & $4-4$ & $3-2$ \\
\hline 7 & $2-3$ & $3-4$ & 1-1 & 4-4 & 1-1 \\
\hline 8 & $2-2$ & $3-3$ & $3-3$ & $4-4$ & $3-3$ \\
\hline 9 & $4-4$ & $2-3$ & $3-3$ & $3-4$ & 4-3 \\
\hline 10 & 3-3 & $2-2$ & 3-3 & 4-4 & 3-3 \\
\hline 11 & $5-3$ & $3-3$ & 4-2 & $1-4$ & 4-3 \\
\hline 12 & 3-3 & $4-3$ & 4-2 & 3-4 & $3-2$ \\
\hline 13 & 4-2 & $2-3$ & $1-2$ & 5-5 & $2-2$ \\
\hline 14 & $3-3$ & $4-4$ & $2-1$ & $4-4$ & $2-4$ \\
\hline 15 & $4-3$ & $3-3$ & 4-3 & $4-4$ & $3-3$ \\
\hline
\end{tabular}




\begin{tabular}{|c|c|c|c|c|c|}
\hline 16 & 4-4 & 3-2 & $2-2$ & 4-4 & 4-3 \\
\hline 17 & $3-4$ & $3-3$ & $1-1$ & $4-4$ & $1-1$ \\
\hline 18 & $2-2$ & $4-4$ & 4-2 & $3-4$ & $2-2$ \\
\hline 19 & $2-3$ & $3-3$ & $1-1$ & 3-4 & $2-2$ \\
\hline 20 & $1-4$ & $1-5$ & 4-1 & $1-1$ & $1-1$ \\
\hline Averages** & $3.05-3.15$ & 2.8-3.35 & $2.55-2.10$ & 3.34-3.83 & 2.65-2.35 \\
\hline Change & 0.1 & 0.55 & -0.45 & 0.49 & -0.3 \\
\hline
\end{tabular}

For the construct of Confidence, the students were probed for changes in using the above question. Scale growth ranged from 0.1 - .55 on a Likert scale for these survey questions. Responses that had growth ceiling Likert scores were not used in the average growth calculations. Of these five questions Q8 “I can plan projects from start to finish" returned significant results, a Wilcoxon matched-pairs, signed ranks test showed that the self-efficacy change from the pre $(\mathrm{Md}=2.8$, Range $=3$, Min, $\max =1,4)$ and post $(\mathrm{Md}=$ 3.35, Range $=3$, Min, $\max =2,5$ ) was significant beyond the .05 level: Asymptotic $\mathrm{p}=.039$ (two-tailed). The sums of ranks were 8.0 and 47.0 for the negative and positive ranks, respectively, therefore $\mathrm{W}=8$. The matched-pairs rank biserial correlation is .41 , which is a 'moderate' effect.

Additionally, Q21 “I can perform a new task when someone shows me how” returned significant results, a Wilcoxon matched-pairs, signed ranks test showed that the self-efficacy change from the pre $(\mathrm{Md}=3.5$, Range $=4$, Min, $\max =1,5)$ and post $(\mathrm{Md}=$ 3.75, Range $=4$, Min, $\max =1,5$ ) was significant beyond the .05 level: Asymptotic $\mathrm{p}=.011$ (two-tailed). The sums of ranks were 0.0 and 28.0 for the negative and positive 
ranks, respectively, therefore $\mathrm{W}=0$. The matched-pairs rank biserial correlation is .13, which is a 'small' effect. The results seem to indicate that after participation in the program the students show a small to moderate increase in their level of confidence. The Wilcoxon signed rank test shows that the observed difference between both measurements is significant. Accordingly, we can reject the null hypothesis that both samples are from the same population.

In classroom observations, the researcher heard and saw different students telling the instructors not to worry about a project they were working on because they "the students” felt that they had the project under control and that they could do it without help from the instructor. These observations of demonstrated confidence in the student's abilities were noticed by the researcher and when brought up in student interviews, many of the students were not aware that this is an example of confidence. Therefore, in the interviews and the survey, many of the students did not indicate a change in their perceived level of confidence.

\section{Problem Solving}

A primary goal of a school is for students to learn in ways that enable them to use what they have learned while at school in new situations outside of the school environment. In short, problem solving is the keystone to education because educators are interested in improving students' ability to solve problems. The sixth and final construct of self-efficacy, Problem solving, was assessed using observations by the researcher in conjunction with personal interviews and by the following questions from the retrospective survey: 
Table 13. Problem Solving

\begin{tabular}{|c|c|c|c|c|c|}
\hline $\begin{array}{l}\text { Problem } \\
\text { Solving }\end{array}$ & $\begin{array}{l}\text { SQ6. I am } \\
\text { able to gather } \\
\text { information } \\
\text { from } \\
\text { different } \\
\text { sources. }\end{array}$ & $\begin{array}{l}\text { SQ12. I } \\
\text { ask } \\
\text { questions } \\
\text { when I do } \\
\text { not } \\
\text { understand } \\
\text { something. }\end{array}$ & $\begin{array}{l}\text { SQ19. I } \\
\text { view } \\
\text { challenging } \\
\text { problems } \\
\text { as tasks to } \\
\text { be } \\
\text { mastered. }\end{array}$ & $\begin{array}{l}\text { SQ22. I } \\
\text { know what } \\
\text { steps to } \\
\text { take to } \\
\text { solve a } \\
\text { problem. }\end{array}$ & $\begin{array}{l}\text { SQ28. } \\
\text { When I } \\
\text { need help } \\
\text { I ask for } \\
\text { it. }\end{array}$ \\
\hline $1 *$ & $4-4$ & $4-4$ & $3-3$ & $4-4$ & $4-4$ \\
\hline 2 & $4-4$ & 3-4 & $3-4$ & 3-4 & $3-3$ \\
\hline 3 & $2-3$ & $4-4$ & $4-4$ & $4-4$ & $2-2$ \\
\hline 4 & $2-4$ & $2-5$ & $2-5$ & $3-4$ & $3-4$ \\
\hline 5 & $3-3$ & $3-3$ & $3-3$ & $3-3$ & $3-3$ \\
\hline 6 & 4-5 & $5-5$ & $3-4$ & 4-5 & 4-5 \\
\hline 7 & 4-5 & $4-4$ & $5-5$ & 4-5 & $5-5$ \\
\hline 8 & $3-3$ & $3-4$ & $3-3$ & $3-3$ & 4-4 \\
\hline 9 & $2-4$ & $4-4$ & $2-3$ & $2-3$ & $4-4$ \\
\hline 10 & $4-4$ & $3-3$ & $3-3$ & $3-3$ & $4-4$ \\
\hline 11 & $2-4$ & $2-4$ & $2-4$ & 3-4 & $3-4$ \\
\hline 12 & $4-4$ & $4-3$ & 3-4 & 3-4 & $3-3$ \\
\hline 13 & $4-4$ & $5-5$ & $4-4$ & $3-4$ & $4-4$ \\
\hline 14 & $3-3$ & 3-4 & $3-3$ & $3-3$ & $4-4$ \\
\hline 15 & $4-4$ & $4-4$ & $4-3$ & $3-4$ & $4-4$ \\
\hline 16 & $4-3$ & $4-4$ & 3-3 & $4-3$ & $4-3$ \\
\hline 17 & $5-5$ & $4-3$ & $5-5$ & 4-4 & $4-2$ \\
\hline 18 & $3-3$ & $4-4$ & 4-4 & $3-3$ & $5-5$ \\
\hline 19 & 3-4 & $4-4$ & $4-4$ & $4-3$ & $4-4$ \\
\hline 20 & $1-3$ & $2-5$ & $1-5$ & $2-2$ & $1-3$ \\
\hline Averages** & $3.16-3.73$ & $3.47-3.9$ & $3-3.67$ & $3.25-3.6$ & $3.5-3.6$ \\
\hline Change & 0.57 & 0.43 & 0.67 & 0.35 & 0.1 \\
\hline \multicolumn{6}{|c|}{$\begin{array}{l}\text { *The scores are the retrospective pre- and post-scores for each item and each } \\
\text { participant. } \\
* * \text { Numeric average of the pre- and post-scores. } \\
* * * \text { Answers negatively coded. }\end{array}$} \\
\hline
\end{tabular}

For the construct of Problem Solving, the students were probed for changes in using the above question. Scale growth ranged from 0.1- .66 on a Likert scale for these 
survey questions. Responses that had growth ceiling Likert scores were not used in the average growth calculations. Of these five questions three returned significant results. Q6 “I am able to gather information from different sources.” returned significant results, a Wilcoxon matched-pairs, signed ranks test showed that the self-efficacy change from the pre $(\mathrm{Md}=3.25$, Range $=4$, Min, $\max =1,5)$ and post $(M d=3.80$, ange $=2$, Min, $\max =3,5$ ) was significant beyond the .05 level: Asymptotic $\mathrm{p}=.018$ (two-tailed). The sums of ranks were 3.0 and 42.0 for the negative and positive ranks, respectively, therefore $\mathrm{W}=3$. The matched-pairs rank biserial correlation is .19 , which is a 'small' effect.

Q19 “I view challenging problems as tasks to be mastered.” returned significant results, a Wilcoxon matched-pairs, signed ranks test showed that the self-efficacy change from the pre $(\mathrm{Md}=3.2$, Range $=4$, Min, $\max =1,5)$ and post $(\mathrm{Md}=3.8$, Range $=2$, Min, $\max =3,5$ ) was significant beyond the .05 level: Asymptotic $p=.031$ (two-tailed). The sums of ranks were 3.0 and 33.0 for the negative and positive ranks, respectively, therefore $W=3$. The matched-pairs rank biserial correlation is .14 , which is a 'small' effect.

Q22 “I know what steps to take to solve a problem.” returned significant results, a Wilcoxon matched-pairs, signed ranks test showed that the self-efficacy change from the pre $(\mathrm{Md}=3.25$, Range $=2$, Min, $\max =2,4)$ and post $(\mathrm{Md}=3.6$, Range $=3$, Min, $\max =$ 2, 5) was significant beyond the .05 level: Asymptotic $p=.035$ (two-tailed). The sums of ranks were 12 and 54 for the negative and positive ranks, respectively, therefore $\mathrm{W}=12$. The matched-pairs rank biserial correlation is .2, which is a 'small' effect. The results seem to indicate that after participation in the program the students show a small 
increased level of self-perceived problem solving abilities, after participation in this program. The Wilcoxon signed rank test shows that the observed difference between both measurements is significant. Consequently, we can reject the null hypothesis that both samples are from the same population, and we might assume that participation in the program caused a significant increase in students' self-perceived problem solving abilities.

In regards to the research question, the study investigated relevant data to determine if there were statistically significant differences from the beginning of the course and the end of the course, as they related to self-efficacy assessment as felt by the students in a PBL program. These findings are consistent with the effects of PBL on selfefficacy in various environments studied in previous research conducted on entire student populations (Zusevics, Lemke, Harley, \& Florsheim, 2013).

\section{Classroom Observations}

Researcher observation notes focused on how students approached the multiple processes of the PBL activity of building the boat, their attitudes during these events, and on students implementing given instructions. Observations looked for physical, as well as verbal signs of engagement such as attentive expressions, raised hands, engagement with materials, note-taking, and interested talk among participants during activities.

Additionally, observations were collected that were of a negative as well as a positive nature to balance out the attitudes that the students held while participating in the course. 
While conducting the observations, the researcher noticed the subtle changes that the students were going through. In the beginning of the wheels most the students were quiet and or self-isolated from the rest of the class. Slowly over the ensuing weeks, the students began to talk amongst themselves more without having to be paired up with another student to get them to converse with each other. By passively listening to these conversations, the researcher was provided insights into how the students were thinking in a manner that was non-intrusive into their assigned projects.

When a new wheel started, and the number of female students increased, there were more noticeable changes that the researcher observed compared to the previous wheel. The male students were much more attentive to the lessons and worked harder on their individual tasks than they had on the last wheel.

Another noticeable change was with the female students. They, as a group, started out complaining about getting dirty or covered in sawdust, and by the end of the wheel, all of them could be found in amongst the males working on the boat not caring about the dirt or sawdust. Many times, they asked for jobs that at the beginning of their wheel, they would have requested that the male students do it instead. Their increased confidence in the environment and skills they were gaining let them seek out new projects.

An example of a construct in action, was when the instructors wanted to have the students design a cabinet to lock up the tools at the end of class. The instructors presented the idea and listed the requirements but not specific details of how to do it. A group of four students volunteered to work on this project and set about how they were going to build the cabinet. They discussed the requirements and planned the design for the 
enclosure. They next drew out plans with the dimensions of the cabinet, to include the materials that would be required to build it. Then they divided up the sections that each of them would do individually and proceeded to work on their sections. Once they had completed their projects, they came back together and assembled the cabinet. The only time the students came to the instructors was for guidance in how some of the parts should be put together. They took ownership of this project and demonstrated motivation, problem-solving and teamwork to build this sub-project that was needed during the overall boat build.

\section{Student Narratives}

\section{Claudia the longest journey}

Claudia is a 16-year-old single parent Hispanic female in her junior year of high school. Claudia began the program from the first wheel and after only a few days became the only female in the initial iteration of the course. Prior to her participation in the program she had a low GPA and demonstrated little interest in social interactions, motivation in school, or the program.

In the first wheel, she was introduced to the various tools of the workshop and the safety rules that would be adhered to for the duration of the program. After initial safety guidelines, we started the process of 'lofting' the boat. Lofting is the process of blowing up the relatively small-scale plans from an architect into full size plans. During this wheel Claudia kept to herself and barely conversed with the other male students. Claudia rarely volunteered to answer any questions, and she had to be prompted daily to begin lofting her portion of the boat. She showed a preference to work one-on-one with one of the 
instructors, over working with other students. Once she was acknowledged as being very neat and meticulous in her work, she began to branch out more and she began to speak more with the other students. Now, she was still apprehensive to be around the tools and the power tools that were in the shop, but the program was still primarily focused on the lofting process. She commented to the instructors and myself multiple times that the tools were for the boys and that she did not want to use them because she did not feel safe around them. She continued to show promise in her drafting skills and she continued to open up as the wheel progressed. By the end of the wheel she was openly talking to more of the other students and even began to joke around with them as well as the instructors.

Her continued attendance in the program continued her evolution in not just attitude but participation as well. "Claudia is a motivating influence to other female students to participate in the program" as stated by one of the school counselors when he came into observe the students working on the boat. Her GPA went from a 1.9 before she entered the program to 2.86 at the end of the project. Claudia had one of the best overall attendance averages at $95 \%$ compared to the overall student average of only $87.5 \%$ for the rest of the classes. Her noticeable improvement in grades, motivation and attitude as the program progressed was demonstrated in how her work quality improved on a weekly basis and in her new-found willingness to assist the new students that came into the program at different wheels. Though the instructors had to prod her to get to work in the beginning by the end she was not only volunteering for new projects but actively seeking out projects that needed to be accomplished before other parts of the boat could be assembled, including being one of only five students to come in on a Saturday to work on 
the boat when it had fallen behind schedule. These actions and attitude manifest her increased self-efficacy. In general, people with high self-efficacy are more likely to make efforts to complete a task, and to persist longer in those efforts, than those with low selfefficacy. The stronger the self-efficacy or mastery expectations, the more active the efforts (Bandura, 1997). After seeing the finished boat, at the end of the program, she stated “I feel inspired!!!! I can’t believe that I made this happen, even though there were many boring days or projects that were difficult for me at first. I can now see what I can do if I keep working at my problems and I will get through them.”

Because Claudia often expressed feelings of inadequacy in school, she demonstrated a sense of low self-efficacy in school. Her doubts about her academic performance, and her sensitivity about her single parent status made her feel like she could not be successful in school. "I come to school so tired every day because I have to get my baby ready and take him to daycare before school starts, then I have school all day and when I get home I have to juggle any homework I have with taking care of my son.” The added stigma of being a single parent while still in school isolates her from other normal social interactions of the other students. However, her continued attendance in the program gave her the opportunity to have increased social interaction in an academic setting, and she started to show an aptitude for the hands-on projects that she did not know she had previously, and she demonstrated an increased outward appearance in her confidence and overall self-awareness. 
Ricardo the unfortunate departure

Ricardo is a 16-year-old Hispanic male in his junior year of high school. Ricardo began the program from the first wheel and was the only male from the initial iteration of the course to participate in all wheels of the course. Ricardo had low grades coming into the program and was very withdrawn from the rest of the class outside of his two other friends that were in the class with him in the first wheel. He rarely talked to other students or even to the staff. He was very proficient with the initial drafting and lofting projects of the course. He continually demonstrated a high level of attention to detail and his work quality was superior to the other student in almost every way. Ricardo rarely had to redo his work and continually showed progress on an almost daily basis. After having his work used as the example as a work well done he started to talk more to the instructors and by the end of his second wheel in the program he had even began to teach the new students to the program the basics to help get them up to speed on working on the boat. His grades improved by the third wheel and he was gaining acclaim with the school for his dramatic turnaround in attendance and academic endeavors as well. He continued to be more of an integral part of the boat building team. Ricardo was also one of the organizers and collaborators for the group of students that came in on the Saturday building session to get the boat back on schedule. He was acknowledged as being the go to guy for many small projects that were needed on the boat and numerous times the researcher noticed that students would go to him to get advice or direction on their projects instead of going to one of the instructors. 
Then when Ricardo entered the fourth wheel everything about him changed. Though his attendance never changed, his attitude and efforts in class did. He became withdrawn once again and stopped volunteering for new projects. Outside of the program his grades dropped back to pre-course levels. His grades before his participation were 1.818, then during the course they were 2.573 , and in his final wheel his grades dropped to 1.638. When asked in his interview by the researcher what had happened to cause the change that was noticed by all staff and other students, he stated that he was tired of the program and felt burnt out after being in the program so long.

Ricardo has now dropped out of school and not maintained contact with his friends that re still in school at the high school. The researcher was notified of this at the official launching of the boat that the students had worked on.

Jason the distracted one

Jason is a 16-year-old white male in his junior year of high school. Jason comes from a single parent home with little contact with his mother, additionally he selfreported to the researcher that he has anger management and ADHD issues. Jason began the program from the first wheel and left the program in the second wheel but returned for a second time in the third wheel of the program. Jason had to struggle with his ADHD almost every day and was very difficult to get engaged in the initial few weeks. The repetitive nature of the lofting process and his ADHD was like oil and water in the classroom environment. There were many days that he would start a project and then just walk away for more than 30 minutes. He talked with me repeatedly about how hard he wanted to work on the boat but he would get distracted relatively easy and his numerous 
friends in the class were not helpful in this regard as well. To keep him engaged in his work an instructor would have to be by his side for much of his time in the first wheel. He had a few outbursts of anger when his frustration levels were high and he was almost not allowed to return to the program in another wheel. These outbursts, as well as, his work output slowly changed in a positive direction. By the end of the first wheel he was working on small projects by himself with fewer nudges by the staff to get him going and his anger issues seemed to be winding down. When he talked with fellow students his comments were less off task and he was collaborating with the other students more and more. He left the program for the next wheel and came back for the third wheel of the program. In his absence from the program he once again fell into his older habits, in his other classes, of talking to other students instead of doing his work and his anger issues became more of a hindrance to his relations with other students. However, after coming back into the program he quickly went back to the Jason that had left the program. When I asked him, what happened while he was out of the program he told me "When I was here I felt that I had something worthwhile to come to school for and the class made school not so boring because he was able to do things with his hands while learning about math and not just everything in a book.” This statement is backed up by looking at his grades coming into the program at a low of 2.06 just prior to his joining the program then going up to 2.2. His GPA then once again dropped down to 1.4 in the wheel that he was out of the program and then when he rejoined his GPA once again rose to 2.1. I discussed this with him during our interview after he had finished his two wheels in the program and I asked him why did he think his grades fluctuated so much over the past four wheels. "I just felt that there was something to do when I was in school while I was a part 
of the program and when I was able to use my hands on a project I was better able to concentrate on what I was doing. Working on the boat showed me that there were skills that I could learn at school that I can take out and use right away. This helped me stay focused when I was there.” This newfound focus he describes is one measure of increased self-efficacy (Cervone, Peake 1986, Ponton, Rhea, 2006).

\section{Paula the Senior that almost quit}

Paula is an 18-year-old Hispanic female in her Senior year of high school. She started the program in the third wheel, and continued through the end of the school year. Though Paula is a very social and popular student, she admitted to the researcher and the other instructors that she felt that she was never very good at school. If you took her at her word you would think that she had bad grades or that she was enrolled in remedial classes, but that would be a wrong assumption. Paula was well on her way to graduating on an expedited schedule that had her graduation date one wheel earlier than the normal school year. Prior to her joining the program she had a GPA of 3.5 and her GPA dropped down to a low of 3.0 once she joined the program. In the first wheel that she attended she complained many times that “the class was for the boys" and she didn't see a point for girls to be in it and she “didn’t see how she would use this stuff”. Her complaining quickly stopped when the project progressed to fine chiseling work that required acute attention to detail and patience in a repetitive laborious project. She was one of only a couple students that not only had the attention to detail required but the perseverance to keep working on the chiseling day in and day out for over three weeks. Her complaints switched from "why am I doing this there are boys around" to "When will this stop so I 
can do a different part of the boat” Another aspect about her that changed was that she was a social butterfly outside of the class but she stated that she felt that she did not fit in with the students in this class and stuck to herself or worked around the instructors only. Once again this changed when she was found to be one of the best at chiseling in the class. She started, on her own, going around helping the other students with their chiseling work that was not as well done as her work. She willingly went on her own to give advice on how they could improve their technique or she would sit and chat with them whereas before she would isolate herself from the other students and not talk to them unless directed to by an instructor.

Just when her progress was starting to become obvious to everyone she said that she was dropping out of school. When asked why, she said that she had just found out that she was pregnant and she did not think that she would be able to continue in the class while pregnant. This occurred when she only had a couple weeks left until she graduated. She came back the next day and informed the instructors that she was going to stay in until the boat was finished. Special arrangements were made for her both in the program and with the school to allow her to stay one wheel longer than needed for her to graduate so that she could see the boat to completion.

Her grades in the last wheel increased to a perfect 4.0 and her engagement with the other students in the final wheel increased as well. She was very outgoing and conversational with the new students from the beginning of the final wheel and continued until the end of the school year when she graduated. 
Adriana the foreman in the making

Adriana is a 16-year-old Hispanic female in her Junior year of high school. She started the program in the third wheel, and continued through the end of the school year. Adriana came into the program barely talking to anyone unless she had to. During her interview, she told the researcher that she hated talking to other people and only wanted to work on projects by herself. Being that this program emphasizes teamwork and collaboration this quickly became an issue with her. The instructors reiterated to her that she would not be able to only work by herself on every aspect of the build. The researcher observed her grudgingly beginning to work with a few of the other female classmates throughout her first wheel that she as in the class. Prior to her joining the program she was in decline from a high of 3.8 in her first wheel at the high school down to a GPA of 3.5. Her GPA continued to drop while in the program down to 2.9 by the end of the school year. When asked why she came back to another wheel she said that she found that she liked working with her hands and that in this class she can do that while still getting math credits. She continued to tell the researcher that before the class she hated the other students but now that she had into interact with them she did not find them so "repulsive”. She continued to interact with the other students and even started to take control of tasks that the instructors gave to the students. She began to organize how the group she was working with would work on their assigned project and she would keep them on task. The researcher observed her many times reprimanding the students in her group for looking at their cell phones or just sitting around doing nothing. When asked about this in her interview she said "I want to finish the boat and I don't want their 
laziness to interfere with that, there are enough problems we have to work around without slackers holding us back." Her manner of talking about the boat changed from "How am I going to get this done” to "How are we going to get this done.” Not only her words but her actions demonstrated this to the instructors and the researcher on an almost daily basis. Adriana became the unofficial foreman of the students in not only her work ethic but her ability to prod the students to get to work without having the instructors asking her to do it. She would ask what was needed before the class started and set about organizing small groups to get them done. 
Chapter 5: Exemplar of the program

One example that demonstrates multiple elements of student self-efficacy in the program, was when five students into school on a Saturday to work on the boat that had fallen behind schedule. When asked about this weekend they said that they knew that the boat was behind schedule and the only way they saw how to get it back on schedule was to come in after school hours but many of them had after school jobs that prevented them from doing it right after class on a normal weekday. They then got together to propose the weekend build session to the instructors and ask if one of them would be able to come into the school so that they could get the boat back on schedule. Not only was this an example of motivation but it also demonstrated that the students saw a problem and figured out a means to fix that problem. Problem solving on another construct of selfefficacy and another aspect of the program that the Wind and Oar Boat School wishes to instill in the students that participate in the program. Their ability to see that there was a problem and then they sought out other students to find a solution for the problem, is an example of the students using their collaborations skills. Many of these students mentioned in their interviews that prior to their participation in the class, that they disliked working with other students let alone talk to them. These students were among the students that had mentioned that they preferred to work independently before being in the course but, they saw a problem and came together to figure out a solution and collaborated amongst themselves as to how they could all come together to work on the boat to get it back to where it needed to be for class on the following Monday. 


\section{Chapter 6: Discussion}

This study sought to measure how the participation in a project-based learning (PBL) activity affected the self-efficacy of at-risk high school students. The data collected from the self-efficacy survey, student interviews, and researcher observations used in this study contributed to answering the researcher's question of how the participation in a project-based learning (PBL) activity of the Wind and Oar Boat School's curriculum affects the self-efficacy of at-risk high school students. The researcher used a self-efficacy survey to answer the research question, which provided data on six constructs of self-efficacy. Those constructs being, Motivation, Course Skills, Confidence, Teamwork, Resilience, and Problem Solving. The survey found positive change in all the constructs. The changes were small nonetheless, yet the study demonstrates that the students felt that there had been positive change after their participation in the program. Not all the changes per survey question were statistically significant. However, all questions did demonstrate shifts in the students that aligned with prior research that the researcher was expecting to observe. The data collected from the survey however only paints one side of the student experience in this program. This required the researcher to utilize student interviews to see the program from the eyes of the participants of the program. 
Table 14. Self-Efficacy Constructs

\begin{tabular}{|l|l|l|}
\hline $\begin{array}{l}\text { Self-Efficacy } \\
\text { Construct: }\end{array}$ & $\begin{array}{l}\text { Curricular opportunities enabling students to } \\
\text { progress for the constructs: }\end{array}$ & $\begin{array}{l}\text { Data sources that document } \\
\text { change for the constructs: }\end{array}$ \\
\hline Motivation & $\begin{array}{l}\text { Daily attendance and participation in the } \\
\text { daily activities of the program }\end{array}$ & $\begin{array}{l}\text { Student interviews, Self- } \\
\text { efficacy Survey, and } \\
\text { Researcher observations }\end{array}$ \\
\hline Course Skills & Applied geometry and fraction calculations & $\begin{array}{l}\text { Student interviews, Self- } \\
\text { efficacy Survey, and } \\
\text { Researcher observations }\end{array}$ \\
\hline Confidence & $\begin{array}{l}\text { Repetition of activities that were new to } \\
\text { students prior to participation in the program }\end{array}$ & $\begin{array}{l}\text { Student interviews, Self- } \\
\text { efficacy Survey, and } \\
\text { Researcher observations }\end{array}$ \\
\hline Teamwork & $\begin{array}{l}\text { Building activities that require more than } \\
\text { one student to accomplish }\end{array}$ & $\begin{array}{l}\text { Student interviews, Self- } \\
\text { efficacy Survey, and } \\
\text { Researcher observations }\end{array}$ \\
\hline Resilience & $\begin{array}{l}\text { Difficult or repetitious tasks that require the } \\
\text { student to finish prior to being able to move } \\
\text { to the next step in the build }\end{array}$ & $\begin{array}{l}\text { Student interviews, Self- } \\
\text { efficacy Survey, and } \\
\text { Researcher observations }\end{array}$ \\
\hline Problem Solving & $\begin{array}{l}\text { Student lead activities that the instructor } \\
\text { only gives the concept and leaves the } \\
\text { student to figure out the details and steps } \\
\text { they need to accomplish the task that was } \\
\text { given to accomplish }\end{array}$ & $\begin{array}{l}\text { Student interviews, Self- } \\
\text { efficacy Survey, and } \\
\text { Researcher observations }\end{array}$ \\
\hline
\end{tabular}

This study sought to measure how the participation in a project-based learning (PBL) activity affected the self-efficacy of at-risk high school students. The data collected from the self-efficacy survey, student interviews, and researcher observations used in this study contributed to answering the researcher's question of how the participation in a project-based learning (PBL) activity of the Wind and Oar Boat School's curriculum affects the self-efficacy of at-risk high school students. The researcher used a self-efficacy survey that provided data on six constructs of self-efficacy To answer the research question, Those constructs being, Motivation, Course Skills, Confidence, Teamwork, Resilience, and Problem Solving. The survey found positive change in all the constructs. The changes were small nonetheless, yet the survey demonstrates that the students felt that there had been positive change after their participation in the program. Not all the changes per survey question were statistically 
significant. However, all questions did demonstrate changes in the students that aligned with prior research that the researcher was expecting to observe. The data collected from the survey however only paints one side of the student experience in this program. This required the researcher to utilize student interviews to see the program from the eyes of the participants of the program.

The interviews provided participant feedback about the same six constructs. The participants described their interpretations of their self-efficacy and explained in their words how they perceived improvement or lack of improvement to the researcher. During some of the interviews, the students were unaware of any changes in how they acted in the program until they were presented evidence from researcher observations. The researcher asked the students if they could explain what the researcher had observed and relate to the researcher if he had misinterpreted their behavior. In much of the interviews, the students were surprised that they had acted at the beginning of the program so differently compared to the end of the program. Upon reflection during the interviews, the students provided greater insight into their actions and the changes they demonstrated over the course of the program.

Classroom Observations provided the researcher the opportunity to compare responses on the survey with the day to day growth of the individual students in regards to self-efficacy. The researcher, by being a participant observer utilized his proximity to the students while they were working on various processes of the build to observe and listen to the conversations of the students. These unfiltered conversations enabled the researcher to understand the choices the students were making and why some days the students were working harder than on other days. The familiarity of the position of 
participant observer afforded the researcher greater access to the actual emotional reasoning that many of the students were feeling throughout the build.

The constructs that demonstrated the most significant change in the participating students were the constructs of Motivation, Resilience, and Course skills. The other constructs of Problem Solving, Teamwork and Confidence, demonstrated positive change as well, but the overall averages of all the questions were slightly lower than the other three constructs. As per the literature on PBL and Self-efficacy these positive changes within these constructs were results that the researcher was expecting to see after participation in a PBL program.

The lower scores from the survey in some of the constructs came as a small surprise to the researcher. Past studies guided the researcher into thinking that PBL activities would demonstrate higher teamwork scores on the survey (Curtis 2002, Katz \& Chard 1999). The average scores from the survey, in and of themselves, do not give the full impact of a single construct. There were individual survey questions that had greater significance than the combined average of the questions of the construct.

In project-based learning, learners work in groups to solve problems that are realistic, curriculum-based, and usually interdisciplinary in scope. Contrary to traditional lessons in PBL activities, the students decide how to approach a problem and what activities will be used to pursue the solution. Students are encouraged to gather information from a variety of sources and synthesize, analyze, and derive knowledge from it. Their learning is fundamentally valuable because it is connected to something tangible and involves skills utilized by adults outside of the classroom, such as collaboration and reflection. Therefore, observable student growth in all the constructs of 
self-efficacy used by the researcher, demonstrate that the theory and practice of PBL programs correlate to increased student self-efficacy.

Perceived self-efficacy also plays an influential role in the exercise of personal control over motivation (Bandura,1988). Beliefs of self-efficacy dictate what people choose or what challenges to undertake, how much effort to expend, and how long to persevere in the face of difficulties.

Student motivation and confidence were by far the two constructs that were the easiest to observe and talk about in student interviews. Motivation also demonstrated the most growth of all the six constructs on the self-efficacy survey. Using the survey in conjunction with researcher observations and the student interviews flushed out the increased level of student motivation as talked about in the exemplar of the program mentioned earlier in this research. The construct of confidence, on the other hand, was more troublesome to ascertain growth. The survey was only able to capture significant results on two of the construct's questions, and the overall combined average of the study's questions that dealt with the construct of confidence had one of the lowest averages compared to the other construct averages.

The difficulty in ascertaining student growth in the survey and observations, in the construct of confidence is problematic if future researchers are looking to replicate a similar study utilizing these constructs. This difficulty may be due to the nature of the students being studied. These students already demonstrate lower levels of confidence than students who are not attending schools designed for at-risk students. This conflicted with researcher observations and student interviews. In the former the students demonstrated increased confidence in their actions throughout the build and 
acknowledged these changes in their interviews, this leads the researcher to conclude that the survey questions may not have been worded in a manner that these students understood to be able to capture the students self-evaluated level of confidence. Another possibility is that these students, are already demonstrating lower self-esteem and the changes in confidence that the researcher and the other instructors observed were not apparent to the students themselves at the time of the survey.

The overall positive change that was observed by the researcher, and documented in the surveys and student interviews demonstrated that thy overall student experience in this program did increase the student self-efficacy. Understandably, the results may only apply to this study due to the small number of participating students. The results are promising. The expected changes in student self-efficacy were observed, and the researcher had few outcomes that were not expected.

The surprising results that came out of this study were how half of the female students wanting to stay in the program longer to see the boat finished. The researcher had not considered gender as a potential variable for this study because the students that had signed up for the course only had one female in the initial attendance list. When the researcher talked about the potential for more female students being part of the study the researcher was informed that historically his program had very few female students that participated in their past builds. Taking this information into account, the researcher chose not to pursue research into the impacts of PBL on female participants. This oversight leaves the potential for further research into this area. The studies on the participation in a PBL activity on female students would have given the researcher direction on what to look for when he was observing the female students and given 
clarity in why their answers were different to the same questions than that of the male students 


\section{Chapter 7: Limitations}

A significant limiting factors in this study was inconsistent course objectives over the duration of the course. The course was divided into four completely different sections that covered the various aspects of the boat building process. Students that participated in the first wheel were engaged in the lofting process as the central theme of the wheel. Lofting dealt with drafting, measurements and accurate drawing of lines of the boat on a full-scale model. Wheel two began building the support structures needed to support the boat during the build. Wheel three concentrated on chiseling and making patterns for the planks. Wheel four assembled the boat into the final product. Students that only participated in one wheel had different working environments and working objectives. Some students participated in more than one iteration of the program while other students were very disengaged in the program, creating differing workloads for the other students. It was observed, that students who participated in more than two consecutive iterations became bored and demonstrated negative responses to new challenges that previously, they had actively participated in or they had sought out on their own.

Another limitation was that not all the instructors fully understood the researcher's role in the program and intervened multiple times with informal interviews that the researcher was conducting to ascertain the feelings of the students as they progressed through the program.

The retrospective pre- post-test used by the researcher proved to be problematic for the students. The students had difficulty understanding the format of the survey and the researcher had to read the instructions many times and the students repeatedly asked the researcher what time frame the questions was referring to on many of the questions. 
This confusion on the part of the students could be due to the high number of ELL's in the program or to the unfamiliarity the students had with this type of survey. Further investigation on this aspect of the study may shed insight on this issue.

Finally, the role of being a participant observer is to gain a more intimate, comprehensive, and nuanced understanding of the participants in the study. However, this familiarity increases the likelihood of the observer becoming biased in their observations and analysis of the observations that are made by the researcher.

There were no obvious limitations to the research design, based on the qualitative data collected in this study. The data gathered from this study suggested that the curriculum used in the intervention was supportive of the participant experience. There are many other constructs that could have been included in the study. The scope of this research experience did not permit the consideration of more than six constructs to evaluate the participants' experiences. In the future, it would be valuable to reexamine the affective components of the study comparing previously validated surveys to this study's instrument to ascertain the level of validity of the survey. This would serve as a repeated measure to track participant affective states over time and by using different tools.

There were some issues that came up during the implementation of the survey instrument. The first being the there were numerous English Language Learners (ELL's) in the course that had difficulty in understanding the questions fully without explanation by the researcher. Also, many of the students had to have the retrospective- aspect of the survey explained in greater detail individually, due to the difficulty they had understanding the format of the study. Additionally, there were some of the questions that 
did not capture the constructs as well as the researcher had planned, which leaves gaps in the potential data that could be collected in the future and give a truer assessment of the students’ self-efficacy. 


\section{Chapter 8: Recommendations}

In the future, If the Wind and Oar Boatbuilding program and the participating high school, truly wanted to make a difference in student self-efficacy, then they should offer the course to Freshmen through Junior classmen instead of to Senior classmen. "The Seniors have already chosen to stay in school and have demonstrated their ability to accomplish goals that they have set up for themselves” as stated by a student. The opportunities this course offers to junior classmen to increase self-efficacy would make a deeper impact on these students. Additionally, I would not allow students to participate in more than two consecutive wheels. This change would prevent the students from getting burnt out on the program and keep the students more actively engaged in the course. This recommendation comes from personal observations of the students over the duration of the program, as well as statements from numerous students that participated in more than one wheel.

Furthermore, the course should have side projects planned to cover the times when the build hits a bottleneck in production. Also, it would be beneficial for the students, if the school had a more active role in the mathematics instruction of the students. Many times, the students were given a building problem that required the use of math and the students were skeptical of the lessons the instructors gave because, in the eyes of the students, the instructors were not math teachers. If the course were to run again, I would suggest that the course begins earlier in the year, and finish before the last wheel of the school year. This would lessen the end of year distractions the students felt and allow for greater engagement by the students. Finally, the program admitted too many senior students into the program. If the Wind and Oar Boat program and 
participating schools truly wanted to affect student self-efficacy, they should have included students that were not already about to graduate. The program should also increase the overall ratio of male to female students. 


\section{Chapter 9: Conclusion}

In the observations, the biggest limitation that the researcher encountered was having to learn how to recognize the different constructs, and how to explain them to other instructors that participated in the program. By taking part the researcher could build rapport with the students, but the resulting relationship that was built between the researcher and the students lead to some of the students wanting to work with the researcher more than with the other instructors. Luckily the students that were prone to cooperate with the researcher more than others were not part of the study so there being distracted by the researcher's presence limited the negative impact on the study.

This study used a PBL based in-school intervention to give high school students the opportunity to learn about the math and creative skills associated with the PBL boatbuilding experience. Previous studies have shown that PBL methodologies may positively impact student attitudes, collaboration, and buy-in, and these factors may contribute to the higher self-efficacy rates as shown in the study (Zusevics, Lemke, Harley \& Florsheim 2013). In this light, we might consider the founding principles of PBL methodology in providing relevant, learner-centered experiences for all students. Although implementing a PBL environment requires ongoing training and support for teachers to be able to integrate PBL methods within complex educational content required by state and national standards, PBL may increase student self-efficacy which leads to greater interest and engagement in school (Bandura 1997).

In conclusion, districts should consider the implementation of PBL as a means of addressing low student self-efficacy issues that may be contributing to low graduation rates. Although previous research has focused on the implementation of PBL across 
school-wide settings, the research has not addressed specific populations for effectiveness. This study provides an initial step in determining the impact of PBL on students, but further research is needed to replicate the results of this study in other environments, and additionally to attempt to eliminate other extraneous variables from consideration in raising self-efficacy in students. More specifically, future research could include statewide comparisons of self-efficacy in students in PBL environments as compared to those in non-PBL schools. Additional studies might include comparisons of self-efficacy assessments of economically disadvantaged students or in small- and medium-sized schools as compared to non-PBL schools of comparable size. Due to the very nature of PBL principles of collaboration relevance to students' lives, and effectively implemented PBL environment may be based on this study's results, meet the personal interests and relevancy of students, therefore leading to increased self-efficacy. 


\section{References}

Bandura, A. (1997). Self-efficacy: The exercise of control. New York: W. H. Freeman.

Bandura, A. (1988). Self-regulation of motivation and action through goal systems.

Cognitive perspectives on emotion and motivation, 37-61.

https://www.beaverton.k12.or.us/schools/merlo-station-chs/, (2016)

Cervone, D., \& Peake, P. (1986). Anchoring, efficacy, and action: The influence of judgmental heuristics on self-efficacy judgments and behavior. Journal of Personality and Social Psychology, 50, 492-501.

Christenson, S., Reschly, A., \& Wylie, C. (2012). Handbook of research on student engagement. New York: Springer Science.

Compas, B., Conner-Smith, J., Saltzman, H., Thomsen, A., \& Wadsworth, M. (2001). Coping with stress during childhood and adolescence: problems, progress, and potential in theory and research. Psychological Bulletin, 127 (1), 87-127

Curtis, D. (2002) The Power of Projects. Educational Leadership 60, 50-53.

Davis, G. (2003). Using retrospective pre-post questionnaire to determine program impact. Journal of Extension, 41(4).

Ercikan, K., Roth, W. (2009). Generalizing from educational research: Beyond qualitative and quantitative polarization. Abingdon: Routledge.

Fredricks, J., Blumenfeld, P., \& Paris, A. (2004). School engagement: Potential of the concept, state of the evidence. Review of Educational Research, 74.

Hammond, B. (2014). Oregon graduation rate barely budges, but most metro districts make big gains. The Oregonian/OregonLive, February 06, 2014 at 7:25 PM. Retrieved from 
http://www.oregonlive.com/education/index.ssf/2014/02/oregon_graduation_rate_ barely.html.

Katz, L., \& Chard, S. (1999). Engaging Children's Minds: The Project Approach 2nd ed.

Larson, R. (2000). Toward a psychology of positive youth development. American Psychologist, 55(1), 170-183.

Locke, E., Frederick, E., Lee, C, \& Bobko, P. (1984). Effect of self-efficacy, goals, and task strategies on task performance. Journal of Applied Psychology, 69, 241-251.

Merriam, S. (2009). Qualitative research: A guide to design and implementation (3rid.). San Francisco, CA: Jossey-Bass.

Pajares, F. \& Miller, D. (1997) Mathematics Self-Efficacy and Mathematical Problem Solving: Implications of Using Different Forms of Assessment, The Journal of Experimental Education, 65:3.

Ponton, M. \& Rhea, N. (2006) Autonomous learning from a social cognitive perspective. New Horizons in Adult Education and Human Resource Development 20(2)

Pratt, C., McGuigan, W., Katzev, A. (2000). Measuring program outcomes: Using retrospective pretest methodology. American Journal of Evaluation, 21(3)

San Martin, T., Calabrese R. (2011). Empowering at-risk students through appreciative inquiry. International Journal of Educational Management, 25(2), pp.110 - 123

Solomon, G. (2003). Project based learning: A primer. TechLearning, Retrieved from http://pennstate.swsd.wikispaces.net/file/view/PBL-Primerwww_techlearning_com.pdf 
Stevens, G. \& Lodl, K. (1999). Community coalitions: Identifying changes in coalition members as a result of training. Journal of Extension [On-line]. 37(2). Available: http://www.joe.org/joe/1999april/rb2.html

Thomas, J. (2000.) A review of research on project-based learning. Retrieved October 2, 2013 from

http://www.bie.org/research/study/review_of_project_based_learning_2000

Zusevics, K., Lemke, M., Harley, A., \& Florsheim, P. (2013). Project health: Evaluation of a project-based health education program. Health Education, 113(3).

EDFacts/Consolidated State Performance Report (2015) school years 2010-11, 2011-12, and 2012-13, http://nces.ed.gov/ccd/tables/ACGR_2010-11_to_2012-13.asp 
Appendix 1

Academic Self-Efficacy and Motivational Resilience

For each of the following statements circle the letter that best describes whether you strongly disagree (SD), disagree (D), are neutral (N), agree (A), or strongly agree (SA) for each of the statements.

\begin{tabular}{|c|c|c|c|c|c|}
\hline Statements & $\begin{array}{l}\text { Strongly } \\
\text { Disagree }\end{array}$ & Disagree & Neutral & Agree & $\begin{array}{l}\text { Strongly } \\
\text { Agree }\end{array}$ \\
\hline $\begin{array}{l}\text { 1. I try my best even when it is a } \\
\text { difficult task }\end{array}$ & & & & & \\
\hline How you feel now & SD & D & $\mathbf{N}$ & A & SA \\
\hline How you felt when the class started & SD & D & $\mathbf{N}$ & A & SA \\
\hline $\begin{array}{l}\text { 2. Things I learn in this class are } \\
\text { not useful outside of school }\end{array}$ & & & & & \\
\hline How you feel now & SD & $\mathbf{D}$ & $\mathbf{N}$ & A & SA \\
\hline How you felt when the class started & SD & $\mathbf{D}$ & $\mathbf{N}$ & $\mathbf{A}$ & SA \\
\hline $\begin{array}{l}\text { 3. I cannot follow complex } \\
\text { instructions unless someone } \\
\text { shows me how to do it }\end{array}$ & & & & & \\
\hline How you feel now & SD & $\mathbf{D}$ & $\mathbf{N}$ & $\mathbf{A}$ & SA \\
\hline How you felt when the class started & SD & $\mathbf{D}$ & $\mathbf{N}$ & $\mathbf{A}$ & SA \\
\hline $\begin{array}{l}\text { 4. I value working with other } \\
\text { students }\end{array}$ & & & & & \\
\hline How you feel now & SD & $\mathbf{D}$ & $\mathbf{N}$ & A & SA \\
\hline How you felt when the class started & SD & $\mathbf{D}$ & $\mathbf{N}$ & $\mathbf{A}$ & SA \\
\hline $\begin{array}{l}\text { 5. Learning to build boats is } \\
\text { interesting to me }\end{array}$ & & & & & \\
\hline How you feel now & SD & $\mathbf{D}$ & $\mathbf{N}$ & $\mathbf{A}$ & SA \\
\hline How you felt when the class started & SD & D & $\mathbf{N}$ & A & SA \\
\hline $\begin{array}{l}\text { 6. I am able to gather information } \\
\text { from different sources }\end{array}$ & & & & & \\
\hline How you feel now & SD & D & $\mathbf{N}$ & A & SA \\
\hline How you felt when the class started & SD & $\mathbf{D}$ & $\mathbf{N}$ & $\mathbf{A}$ & SA \\
\hline
\end{tabular}




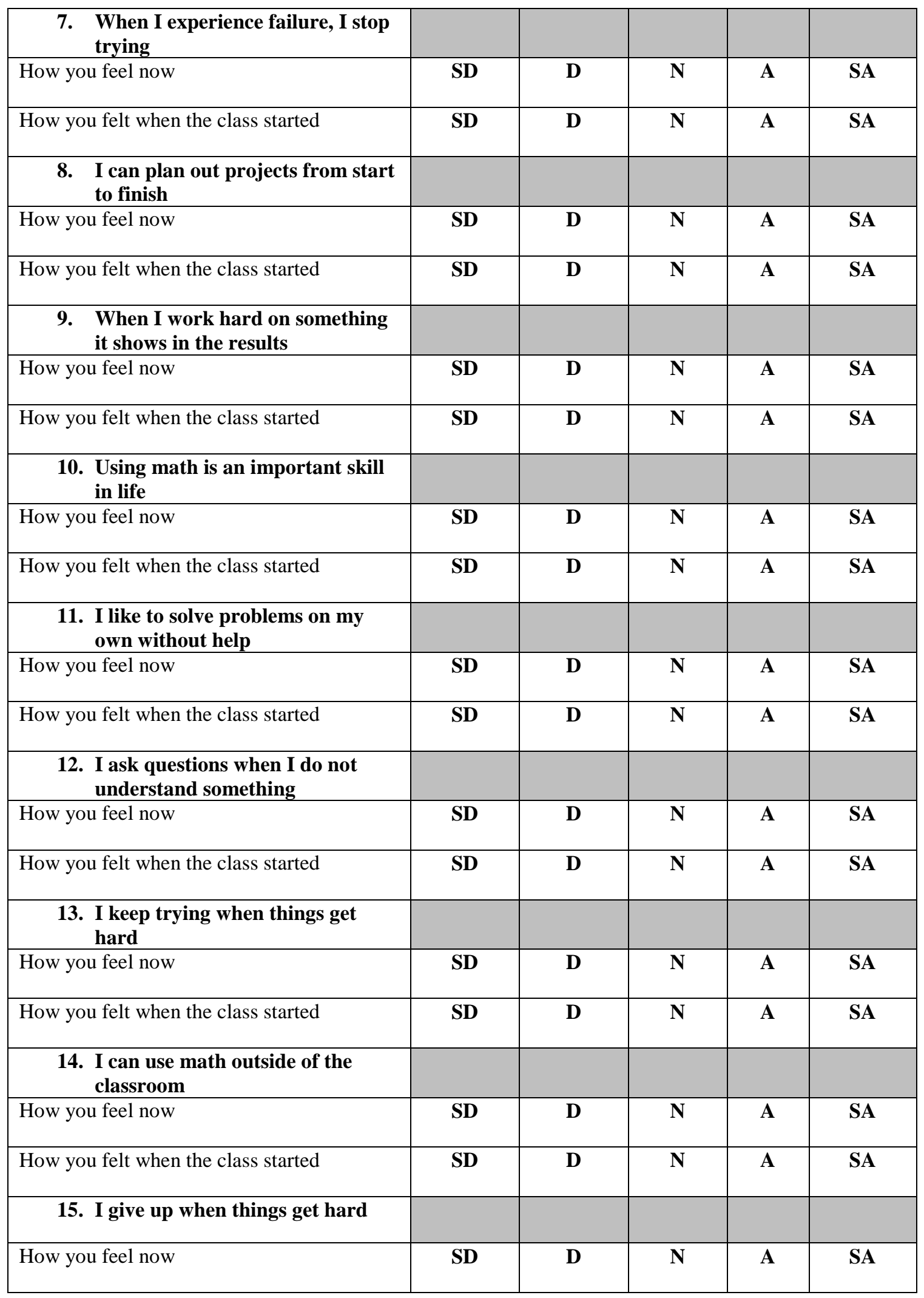




\begin{tabular}{|c|c|c|c|c|c|}
\hline How you felt when the class started & SD & $\mathbf{D}$ & $\mathbf{N}$ & $\mathbf{A}$ & SA \\
\hline \multicolumn{6}{|c|}{$\begin{array}{l}\text { 16. I believe that difficult tasks are } \\
\text { beyond my capabilities }\end{array}$} \\
\hline How you feel now & SD & $\mathbf{D}$ & $\mathbf{N}$ & A & SA \\
\hline How you felt when the class started & SD & D & $\mathbf{N}$ & $\mathbf{A}$ & SA \\
\hline \multicolumn{6}{|c|}{ 17. I can learn from my classmates } \\
\hline How you feel now & SD & $\mathbf{D}$ & $\mathbf{N}$ & $\mathbf{A}$ & SA \\
\hline How you felt when the class started & SD & D & $\mathbf{N}$ & $\mathbf{A}$ & SA \\
\hline \multicolumn{6}{|l|}{ 18. I care about my project } \\
\hline How you feel now & SD & $\mathbf{D}$ & $\mathbf{N}$ & $\mathbf{A}$ & SA \\
\hline How you felt when the class started & SD & $\mathbf{D}$ & $\mathbf{N}$ & A & SA \\
\hline \multicolumn{6}{|c|}{$\begin{array}{l}\text { 19. I view challenging problems as } \\
\text { tasks to be mastered }\end{array}$} \\
\hline How you feel now & SD & D & $\mathbf{N}$ & $\mathbf{A}$ & SA \\
\hline How you felt when the class started & SD & $\mathbf{D}$ & $\mathbf{N}$ & $\mathbf{A}$ & SA \\
\hline \multicolumn{6}{|l|}{$\begin{array}{l}\text { 20. I can make valuable } \\
\text { contributions to a project }\end{array}$} \\
\hline How you feel now & SD & D & $\mathbf{N}$ & A & SA \\
\hline How you felt when the class started & SD & $\mathbf{D}$ & $\mathbf{N}$ & $\mathbf{A}$ & SA \\
\hline \multicolumn{6}{|c|}{$\begin{array}{l}\text { 21. I can perform a new task when } \\
\text { someone shows me how }\end{array}$} \\
\hline How you feel now & SD & $\mathbf{D}$ & $\mathbf{N}$ & $\mathbf{A}$ & SA \\
\hline How you felt when the class started & SD & D & $\mathbf{N}$ & A & SA \\
\hline \multicolumn{6}{|c|}{$\begin{array}{l}\text { 22. I know what steps to take to solve } \\
\text { a problem }\end{array}$} \\
\hline How you feel now & SD & D & $\mathbf{N}$ & A & SA \\
\hline How you felt when the class started & SD & $\mathbf{D}$ & $\mathbf{N}$ & $\mathbf{A}$ & SA \\
\hline \multicolumn{6}{|c|}{$\begin{array}{l}\text { 23. Learning to do math is important } \\
\text { to me }\end{array}$} \\
\hline How you feel now & SD & D & $\mathbf{N}$ & $\mathbf{A}$ & SA \\
\hline How you felt when the class started & SD & $\mathbf{D}$ & $\mathbf{N}$ & $\mathbf{A}$ & SA \\
\hline 24. I avoid challenging tasks & & & & & \\
\hline
\end{tabular}




\begin{tabular}{|c|c|c|c|c|c|}
\hline How you feel now & SD & D & N & A & SA \\
\hline How you felt when the class started & SD & D & N & A & SA \\
\hline 25. I can use math on a project & & & & & \\
\hline How you feel now & SD & D & N & A & SA \\
\hline How you felt when the class started & SD & D & N & A & SA \\
\hline $\begin{array}{c}\text { 26. I am able to try harder when the } \\
\text { teacher gives me encouragement }\end{array}$ & SD & D & N & A & SA \\
\hline $\begin{array}{c}\text { How you feel now } \\
\text { How you felt when the class started }\end{array}$ & SD & D & N & A & SA \\
\hline 27. recover quickly from setbacks & & & & & \\
\hline How you feel now & SD & D & N & A & SA \\
\hline How you felt when the class started & SD & D & N & A & SA \\
\hline 28. When I need help I ask for it & & & & & \\
\hline $\begin{array}{l}\text { How you feel now } \\
\text { How you felt when the class started } \\
\text { projects }\end{array}$ & SD & D & N & A & SA \\
\hline $\begin{array}{l}\text { How you felt when the class started } \\
\text { SD }\end{array}$ & D & N & A & SA \\
\hline
\end{tabular}

